\title{
Marine Organisms from the Yucatan Peninsula (Mexico) as a Potential Natural Source of Antibacterial Compounds
}

\author{
Dawrin Pech-Puch ${ }^{1}{ }^{1}$, Mar Pérez-Povedano ${ }^{1}$, Patricia Gómez ${ }^{2}$, Marta Martínez-Guitián ${ }^{3}$, \\ Cristina Lasarte-Monterrubio ${ }^{3}{ }^{(D)}$, Juan Carlos Vázquez-Ucha ${ }^{3}{ }^{(D)}$, \\ María Lourdes Novoa-Olmedo ${ }^{3}$, Sergio Guillén-Hernández ${ }^{4}$ iD, Harold Villegas-Hernández 4 (D), \\ Germán Bou $^{3}$, Jaime Rodríguez ${ }^{1, * \mathbb{D}}$, Alejandro Beceiro ${ }^{3}$ and Carlos Jiménez $^{1, * \mathbb{D}}$ \\ 1 Centro de Investigacións Científicas Avanzadas (CICA) e Departmento de Química, Facultade de Ciencias, \\ AE CICA-INIBIC, Universidade da Coruña, 15071 A Coruña, Spain; dawrin.j.pech@udc.es (D.P.-P.); \\ perezpovedanomaranabel@gmail.com (M.P.-P.) \\ 2 Unidad Académica de Ecología y Biodiversidad Acuática, Instituto de Ciencias del Mar y Limnología, \\ Universidad Nacional Autónoma de México, CDMX 04510, Mexico; patricia@cmarl.unam.mx \\ 3 Servicio de Microbioloxía, Instituto de Investigación Biomédica AE CICA-INIBIC, Complexo Hospitalario \\ Universitario A Coruña, 15006 A Coruña, Spain; m.martinez.guitian@gmail.com (M.M.-G.); \\ crlasarm@gmail.com (C.L.-M.); juan.vazquez@udc.es (J.C.V.-U.); marianovoa@usb.ve (M.L.N.-O.); \\ German.Bou.Arevalo@sergas.es (G.B.); Alejandro.Beceiro.Casas@sergas.es (A.B.) \\ 4 Departamento de Biología Marina, Campus de Ciencias Biológicas y Agropecuarias, Universidad Autónoma \\ de Yucatán, Carretera Mérida-Xmatkuil Km. 15.5, Mérida C.P. 97000, Yucatán, Mexico; \\ ghernand@correo.uady.mx (S.G.-H.); harold.villegas@correo.uady.mx (H.V.-H.) \\ * Correspondence: jaime.rodriguez@udc.es (J.R.); carlos.jimenez@udc.es (C.J.)
}

Received: 18 June 2020; Accepted: 15 July 2020; Published: 18 July 2020

\begin{abstract}
A total of 51 sponges (Porifera) and 13 ascidians (Chordata) were collected on the coast of the Yucatan Peninsula (Mexico) and extracted with organic solvents. The resulting extracts were screened for antibacterial activity against four multidrug-resistant (MDR) bacterial pathogens: the Gram-negative Acinetobacter baumannii, Klebsiella pneumoniae, and Pseudomonas aeruginosa and the Gram-positive Staphylococcus aureus. The minimum inhibitory concentrations (MICs) of the organic extracts of each marine organism were determined using a broth microdilution assay. Extracts of eight of the species, in particular the Agelas citrina and Haliclona (Rhizoniera) curacaoensis, displayed activity against some of the pathogens tested. Some of the extracts showed similar MIC values to known antibiotics such as penicillins and aminoglycosides. This study is the first to carry out antimicrobial screening of extracts of marine sponges and ascidians collected from the Yucatan Peninsula. Bioassay-guided fractionation of the active extracts from the sponges Amphimedon compressa and A. citrina displayed, as a preliminary result, that an inseparable mixture of halitoxins and amphitoxins and (-)-agelasine B, respectively, are the major compounds responsible for their corresponding antibacterial activities. This is the first report of the antimicrobial activity of halitoxins and amphitoxins against major multidrug-resistant human pathogens. The promising antibacterial activities detected in this study indicate the coast of Yucatan Peninsula as a potential source of a great variety of marine organisms worthy of further research.
\end{abstract}

Keywords: sponges; ascidians; antimicrobial; multidrug-resistance; Yucatan Peninsula 


\section{Introduction}

The Yucatan Peninsula in Mexico is the area where the great Mayan culture became established and developed. The Maya people had extensive knowledge about the natural resources available and they maintained a long tradition of using the flora and fauna from the region to meet their basic needs in relation to food, health, and housing. In a recent large ethnobiological study of contemporary Mayan culture [1], is reported that some 145 of the estimated 2300 vascular plants known to grow in the region were used as food sources, while another 680 are used for medicinal purposes. The same study refers to different applications of various wildlife species: 81 terrestrial vertebrates, mainly reptiles, birds, and mammals, were used as food sources, and at least 40 wild vertebrates were used for medicinal purposes. More specifically, in relation to marine resources, 62 teleostean, 3 elasmobranch, 4 molluscan, and 4 crustacean species were commercially harvested [1].

The discovery of the remains of toxic marine animals, such as stingrays, puffer fishes, cone snails, sponges, and corals, in the caches of archaeological sites of the ancient Mayan civilization indicated that the venoms or toxins of these organisms may have been used for specific purposes, e.g., to induce pain or in ritual contexts [1]. Sponges were also used in ancient Greek civilization for medical and pharmacological purposes because of their absorbent, compressive, and sterile properties [2]. However, direct uses for marine organisms in Mayan culture are not known in many cases.

Antimicrobial resistance (AMR) has become a global health emergency and is placing the great achievements made with the discovery of antibiotics in the 20th century at risk. The use and development of antibiotics did not take into account the rapid evolution of the bacteria being targeted, and antimicrobial resistance has emerged hand in hand with the routine clinical use of antibiotics. It has been estimated that AMR is responsible for more than 25,000 deaths a year in the European Union, and it has been predicted that this number could rise to more than 10 million deaths worldwide by 2050, overcoming pathologies such as cancer and heart disease [3]. In addition, AMR has been estimated to cause economic losses of 1.5 billion euros a year in European health systems. International organizations, such as the Food and Agriculture Organization (FAO), the World Organisation for Animal Health (OIE), and the World Health Organization (WHO), have established AMR as one of the main research objectives within the field of health in the next decade. This scenario indicates the need for extraordinary efforts to be made both from scientific and academic communities and from society in general, in the search for solutions to this global health problem.

The WHO has published a list of priority pathogens for R\&D of new antibiotics. The list includes various species identified as of critical priority, such as Acinetobacter baumannii, the carbapenem-resistant Enterobacterales and Pseudomonas aeruginosa, and several species identified as being of high priority, such as Staphylococcus aureus, which is resistant to methicillin and vancomycin [4]. Hospital outbreaks caused by these pathogens have increased significantly in recent decades, causing serious health problems [5]. Carbapenems are last-line antibiotics used to treat multiresistant strains of these Gram-negative pathogens. However, resistance to these antimicrobials increased substantially in the first decade of this century [6]. Colistin is one of the few remaining antimicrobials that is effective against these Gram-negative pathogens, with resistance rates below 10\%. Unfortunately, there are important drawbacks associated with the use of colistin, including high nephrotoxicity, poor distribution in cerebrospinal fluid and lung, and rapidly increasing resistance rates [7]. Under these circumstances, the need for new therapeutic options for the treatment of multi-resistant pathogen infections is indisputable. Most recently developed antimicrobials are derived from already known antibiotics. The discovery of new antimicrobials is closely followed by the development of resistance to these, and drugs with new mechanisms of action that overcome the current mechanisms of resistance are urgently required [8].

The oceans have become an important natural source of bioactive molecules, mainly because they cover a great proportion of Earth's surface (more than 70\%) and are highly diverse ecosystems. The distinctive physical and chemical conditions of the marine environment facilitate the production of molecules with unique structural, chemical, and biological characteristics that are not found in 
natural products isolated from terrestrial sources [9]. Most of the biological activities associated with marine natural products are cytotoxic and anticancer properties [10]. Natural products and their derivatives that can be related to molecules isolated from marine organisms and which have been approved as therapeutic agents belong to six structural types [11]. The alkaloid Yondelis $($ (trabectedin, ecteinascidin 743), a marine natural product isolated from the tunicate Ecteinascidia turbinata [12], and the antibody-drug conjugate (ADC) Adcetris $($ (brentuximab vedotin), a derivative of dolastatin 10 , originally isolated from extracts of the sea hare Dolabella auricularia [13], represent two examples of anticancer agents approved by the US Food and Drug Administration (FDA). Moreover, a large number of marine-derived drug candidates are currently under evaluation in clinical trials. Porifera (sponges) and Cnidaria (soft corals), along with marine microorganisms, are currently the most productive sources of new natural products [14].

In tropical waters, species and their predators compete strongly for space, and marine organisms produce secondary metabolites as chemical defence mechanisms [15]. Mexico has been considered one of the three areas in the world with the highest terrestrial and marine biological diversity [16], and although the chemical diversity of the Mexican medicinal flora has long been investigated, yielding a wide variety of bioactive compounds [17], the chemical potential of the marine resources has not been widely explored [18]. The Mexican territory covers an area of 2,946,825 km $\mathrm{km}^{2}$ and has $11,122 \mathrm{~km}$ of coastline, which extends from the Pacific Ocean to the Caribbean Sea and the Gulf of Mexico, including the Baja California peninsula (northwest) and the Yucatan peninsula (southeast), which hosts a rich marine flora and fauna [19]. More specifically, the Gulf of Mexico and the Caribbean Sea, which meet in the Yucatan channel, constitute two outstanding marine ecosystems. This particular geographical location promotes the existence of a high diversity and abundance of different marine species, which represent a potential source of bioactive compounds and food [20]. The Yucatan Peninsula occupies $17.4 \%$ of the coastline of Mexico and has a great biological diversity on the shore and in the ocean. Moreover, it has a considerable extension of shores and other biological zones, such as mangrove forests, tropical reefs, and protected natural areas (Celestún, Ría Lagartos, Dzilam de Bravo, and Alacranes Reef, among others), where the chemical properties of natural products remain untapped [19]. The few studies of marine organisms collected from the Yucatan peninsula have focused almost exclusively on describing the biological activities of the organic extracts, mainly antibacterial [20], antifungal [20], antioxidant [21], antiparasitic [22,23], ichtyotoxic [24], and cytotoxic [25] extracts. Most of the marine organisms that have been studied are algae, with fewer studies of cnidarians and holothuroids, and very few of sponges and tunicates [26,27].

In light of this background, we have begun a research project focusing on the chemistry and biological activity of sponges and ascidians from the Yucatan Peninsula [28]. In this article, we report the evaluation of the antibacterial activity of 64 organic extracts from marine invertebrate species collected along the coasts of the Yucatan Peninsula, selected on the basis of chemotaxonomic criteria. We prioritized those species of marine organisms belonging to genera or families from which compounds with unusual structures have been extracted or that have previously shown remarkable biological activity. Two of the active sponge extracts were further fractionated and the major compounds responsible for the antimicrobial activity were isolated.

\section{Results and Discussion}

\subsection{Animal Material Studies}

A total of 64 marine organisms (51 sponges and 13 ascidians) were collected from two different species-rich ecosystems in the Yucatan Peninsula in Mexico: a coral reef and a mangrove forest. For the collection, specimens belonging to genera or families, from which structurally novel compounds had previously been extracted and/or that displayed interesting biological activities, were prioritized (selected from SciFinder and Antimarin databases by applying chemotaxonomic criteria). Each organism was exhaustively extracted (three times) with a mixture of dichloromethane-methanol (1:1) to produce 
the corresponding organic extract. Aliquots of each extract were evaluated in antibacterial activity tests using the gold standard broth microdilution method.

The bacterial pathogens A. baumannii, P. aeruginosa, Klebsiella pneumoniae, and S. aureus were used as test strains in this study because they form part of the ESKAPE group (an acronym that gather the names of six bacterial pathogens commonly associated with antimicrobial resistance), recognised as some of the most clinically relevant nosocomial pathogens. We have included, in this study, two strains of every bacterial species: one strain susceptible to classical antimicrobials and one a multidrug-resistant strain (Tables S1 and S2). There is an urgent and growing need for new classes of antibiotics to use in therapies that can ensure the level of infection control required in medical procedures [29].

In clinical microbiology, microbial susceptibility is defined by breakpoints, which are the lowest antibiotic concentrations that inhibit bacterial growth of any strains lacking resistance mechanisms [9]. Thus, the MICs are very valuable as a standardized measure of the antibiotic activity against bacteria. We established three categories of antibacterial activity to classify the marine extracts: high activity (minimum inhibitory concentration (MIC) $\leq 8 \mathrm{mg} / \mathrm{L}$ ), intermediate activity (MIC 16-64 mg/L), and low or no activity (MIC $\geq 128 \mathrm{mg} / \mathrm{L}$ ).

Of the 64 extracts tested, 9 displayed antimicrobial activity against one or more bacterial pathogens, according to the aforementioned classification. All extracts from tunicates were found to be inactive while the active extracts were derived from eight sponges: Agelas citrina, Agelas dilatata, Agelas sceptrum, Aiolochroia crassa (collected from two different locations: Mahahual in Quintana Roo state and Alacranes Reef in Yucatan state), Amphimedon compressa, Dysidea sp., Monanchora arbuscula, and Haliclona (Rhizoniera) curacaoensis (Table 1). Three of these sponges showed antimicrobial activity against all the four bacterial strains tested. A. citrina showed the highest activity (MIC of $8 \mathrm{mg} / \mathrm{L}$ for the three Gram-negative species and a MIC of $0.5 \mathrm{mg} / \mathrm{L}$ for the Gram-positive S. aureus), followed by A. compressa with a MIC of $32 \mathrm{mg} / \mathrm{L}$ for the four bacterial species and finally $H$. (Rhizoniera) curacaoensis, with a MIC of $4-32 \mathrm{mg} / \mathrm{L}$ for the three Gram-negative and a MIC of $4 \mathrm{mg} / \mathrm{L}$ for $S$. aureus. The remaining five extracts displayed antimicrobial activity, with MIC values ranging from 16 to $128 \mathrm{mg} / \mathrm{L}$. Thus, the M. arbuscula extract showed good activity against $S$. aureus, with a MIC of $16 \mathrm{mg} / \mathrm{L}$, but was inactive against the three Gram-negative bacteria. The Dysidea sp. extract also displayed antibacterial activity, with MIC values of 16 and $32 \mathrm{mg} / \mathrm{L}$ for $A$. baumannii and S. aureus, respectively. The A. dilatata extract yielded MIC values of 32-128 mg/L for two of the Gram-negative bacteria and a MIC of $64 \mathrm{mg} / \mathrm{L}$ for S. aureus. For the extracts of $A$. crassa collected from two different sites, the MIC values ranged from $32-64 \mathrm{mg} / \mathrm{L}$ for A. baumannii and S. aureus. Finally, the A. sceptrum extract yielded a MIC value of $64 \mathrm{mg} / \mathrm{L}$ for P. aeruginosa (Table 1 ).

Comparison of the MICs with those of known antibiotics revealed the high activity of some extracts. For example, penicillins (piperacillin and ticarcillin) and even carbapenems (meropenem) belonging to the $\beta$-lactam antibiotic group, for which MIC values of less than, respectively, $16 \mathrm{mg} / \mathrm{L}$ and of less than $8 \mathrm{mg} / \mathrm{L}$ for the causative strain, are used successfully to treat infections caused by Gram-negative pathogens. Aminoglycosides (e.g., amikacin), for which MICs of less than $16 \mathrm{mg} / \mathrm{L}$ have been determined, are generally clinically effective against Gram-negative species. For example, teicoplanin and linezolid are widely used to treat infections caused by $S$. aureus and are effective against strains with which MICs of less than $4 \mathrm{mg} / \mathrm{L}$ have been determined. Antibiotics such as fosfomycin, with low toxicity or adequate PK/PD parameters, reach high concentrations in serum and can be used to treat strains for which MICs $<32 \mathrm{mg} / \mathrm{L}$ have been determined [30]. 
Table 1. Minimum inhibitory concentrations (MICs in mg/L) of organic extracts of marine organisms from the Yucatan Peninsula.

\begin{tabular}{|c|c|c|c|c|c|c|}
\hline Phylum & Order & Family, Species (Code) & $\begin{array}{l}\text { A. baumanni } \\
\text { ATCC } 17978\end{array}$ & $\begin{array}{l}\text { K. pneumonia } \\
\text { ATCC } 700603\end{array}$ & $\begin{array}{l}\text { P. aeruginosa } \\
\text { ATCC } 27823\end{array}$ & $\begin{array}{c}\text { S. aureus } \\
\text { ATCC } 29213\end{array}$ \\
\hline \multirow{13}{*}{ Chordata } & \multirow{9}{*}{ Aplousobranchia } & $\begin{array}{c}\text { Clavelinidae } \\
\text { Clavelina sp. (T18-M1) }\end{array}$ & $\geq 512$ & $\geq 512$ & $\geq 512$ & $\geq 512$ \\
\hline & & $\begin{array}{c}\text { Didemnidae } \\
\text { Didemnum perlucidum (E8-2) }\end{array}$ & $\geq 512$ & $\geq 512$ & $\geq 512$ & $>512$ \\
\hline & & Didemnum sp. (T18-M4) & $\geq 512$ & $\geq 512$ & $\geq 512$ & $\geq 512$ \\
\hline & & Didemnum sp. (E01) & $\geq 512$ & $\geq 512$ & $\geq 512$ & $\geq 512$ \\
\hline & & Trididemnum solidum (E7-2) & $\geq 512$ & $\geq 512$ & $>512$ & $>512$ \\
\hline & & Polysyncraton sp. (EY18-8) & $\geq 512$ & $\geq 512$ & $\geq 512$ & $\geq 512$ \\
\hline & & $\begin{array}{c}\text { Polycitoridae } \\
\text { Eudistoma amanitum (RIO18-T1) }\end{array}$ & $\geq 512$ & $\geq 512$ & $\geq 512$ & $\geq 512$ \\
\hline & & Eudistoma sp. (TY18-2) & $\geq 512$ & $\geq 512$ & $\geq 512$ & $\geq 512$ \\
\hline & & $\begin{array}{c}\text { Polyclinidae } \\
\text { Polyclinum sp. (T18-M5) }\end{array}$ & $\geq 512$ & $\geq 512$ & $\geq 512$ & $\geq 512$ \\
\hline & \multirow{2}{*}{ Phlebobranchia } & $\begin{array}{c}\text { Ascidiidae } \\
\text { Phallusia nigra (TY18-1) }\end{array}$ & $\geq 512$ & $\geq 512$ & $\geq 512$ & $\geq 512$ \\
\hline & & $\begin{array}{c}\text { Perophoridae } \\
\text { Ecteinascidia sp. (T18-M2) }\end{array}$ & $\geq 512$ & $\geq 512$ & $\geq 512$ & $\geq 512$ \\
\hline & \multirow{2}{*}{ Stolidobranchia } & $\begin{array}{c}\text { Molgulidae } \\
\text { Molgula sp. (T18-M6) }\end{array}$ & $\geq 512$ & $\geq 512$ & $\geq 512$ & $\geq 512$ \\
\hline & & $\begin{array}{c}\text { Styelidae } \\
\text { Polycarpa sp. (E41) }\end{array}$ & $\geq 512$ & $\geq 512$ & $\geq 512$ & $\geq 512$ \\
\hline
\end{tabular}


Table 1. Cont

\begin{tabular}{|c|c|c|c|c|c|c|}
\hline Phylum & Order & Family, Species (Code) & $\begin{array}{l}\text { A. baumanni } \\
\text { ATCC } 17978\end{array}$ & $\begin{array}{l}\text { K. pneumonia } \\
\text { ATCC } 700603\end{array}$ & $\begin{array}{l}\text { P. aeruginosa } \\
\text { ATCC } 27823\end{array}$ & $\begin{array}{c}\text { S. aureus } \\
\text { ATCC } 29213\end{array}$ \\
\hline \multirow{20}{*}{ Porifera } & \multirow{5}{*}{ Agelasida } & $\begin{array}{c}\text { Agelasidae } \\
\text { Agelas citrina (CZE56) }\end{array}$ & 8 & 8 & 8 & 0.5 \\
\hline & & Agelas clathrodes (E27-2) & $\geq 512$ & $\geq 512$ & $\geq 512$ & $>512$ \\
\hline & & Agelas clathrodes (MA18-10) & $\geq 512$ & $\geq 512$ & $\geq 512$ & $\geq 512$ \\
\hline & & Agelas dilatata (E25-1) & 128 & 64 & 32 & 64 \\
\hline & & Agelas sceptrum (E26-2) & $\geq 512$ & 256 & 64 & $>512$ \\
\hline & \multirow{3}{*}{ Axinellida } & $\begin{array}{c}\text { Heteroxyidae } \\
\text { Myrmekioderma gyroderma (CZE18) }\end{array}$ & $\geq 512$ & $\geq 512$ & $\geq 512$ & $\geq 512$ \\
\hline & & $\begin{array}{c}\text { Raspailiidae } \\
\text { Ectyoplasia ferox (MA18-9) }\end{array}$ & $\geq 512$ & $\geq 512$ & $\geq 512$ & $\geq 512$ \\
\hline & & Ectyoplasia sp. (MA18-13) & $\geq 512$ & $\geq 512$ & $\geq 512$ & $\geq 512$ \\
\hline & \multirow{2}{*}{ Chondrillida } & \multirow{2}{*}{$\begin{array}{c}\text { Chondrillidae } \\
\text { Chondrilla caribensis } f \text {. hermatypica (MA18-6) } \\
\text { Chondrilla sp. (RIO18-1) }\end{array}$} & $\geq 512$ & $\geq 512$ & $\geq 512$ & $\geq 512$ \\
\hline & & & $\geq 512$ & $\geq 512$ & $\geq 512$ & $\geq 512$ \\
\hline & \multirow{2}{*}{ Clathrinida } & $\begin{array}{c}\text { Clathrinidae } \\
\text { Clathrina sp. (EY18-10) }\end{array}$ & $\geq 512$ & $\geq 512$ & $\geq 512$ & $\geq 512$ \\
\hline & & $\begin{array}{c}\text { Leucettidae } \\
\text { Leucetta floridana (E2-2) }\end{array}$ & 128 & 256 & $\geq 512$ & 128 \\
\hline & \multirow{2}{*}{ Clionaida } & $\begin{array}{c}\text { Clionaidae } \\
\text { Cliona delitrix (EY18-1) }\end{array}$ & $\geq 512$ & $\geq 512$ & $\geq 512$ & $\geq 512$ \\
\hline & & Cliona varians (EY18-3) & $\geq 512$ & $\geq 512$ & $\geq 512$ & $\geq 512$ \\
\hline & \multirow{6}{*}{ Dictyoceratida } & $\begin{array}{c}\text { Dysideidae } \\
\text { Dysidea sp. (EY18-12) }\end{array}$ & 16 & $\geq 512$ & $\geq 512$ & 32 \\
\hline & & $\begin{array}{c}\text { Irciniidae } \\
\text { Ircinia felix (E9-2) }\end{array}$ & $\geq 512$ & $\geq 512$ & $\geq 512$ & $>512$ \\
\hline & & Ircinia felix (MA18-11) & $\geq 512$ & $\geq 512$ & $\geq 512$ & $\geq 512$ \\
\hline & & Ircinia strobilina (E24-2) & $\geq 512$ & $\geq 512$ & $\geq 512$ & $>512$ \\
\hline & & Ircinia strobilina (E52) & $\geq 512$ & $\geq 512$ & $\geq 512$ & $\geq 512$ \\
\hline & & $\begin{array}{c}\text { Spongiidae } \\
\text { Spongia tubulifera (E11-2) }\end{array}$ & $\geq 512$ & $\geq 512$ & $\geq 512$ & $\geq 512$ \\
\hline
\end{tabular}


Table 1. Cont

\begin{tabular}{|c|c|c|c|c|c|c|}
\hline Phylum & Order & Family, Species (Code) & $\begin{array}{l}\text { A. baumanni } \\
\text { ATCC } 17978\end{array}$ & $\begin{array}{l}\text { K. pneumonia } \\
\text { ATCC } 700603\end{array}$ & $\begin{array}{l}\text { P. aeruginosa } \\
\text { ATCC } 27823\end{array}$ & $\begin{array}{c}\text { S. aureus } \\
\text { ATCC } 29213\end{array}$ \\
\hline \multirow{19}{*}{ Porifera } & \multirow{10}{*}{ Haplosclerida } & $\begin{array}{c}\text { Callyspongiidae } \\
\text { Callyspongia longissima (E28) }\end{array}$ & $\geq 512$ & $\geq 512$ & $\geq 512$ & $\geq 512$ \\
\hline & & Callyspongia plicifera (E31) & $\geq 512$ & $\geq 512$ & $\geq 512$ & $\geq 512$ \\
\hline & & Callyspongia vaginalis (E16) & $\geq 512$ & $\geq 512$ & $\geq 512$ & $\geq 512$ \\
\hline & & $\begin{array}{c}\text { Chalinidae } \\
\text { Haliclona (Rhizoniera) curacaoensis (EY18-4) }\end{array}$ & 4 & 16 & 32 & 4 \\
\hline & & $\begin{array}{c}\text { Niphatidae } \\
\text { Amphimedon compressa (E29) }\end{array}$ & 32 & 32 & 32 & 32 \\
\hline & & Niphates digitalis (E15) & $\geq 512$ & $\geq 512$ & $\geq 512$ & $\geq 512$ \\
\hline & & Niphates erecta (E49) & $\geq 512$ & $\geq 512$ & $\geq 512$ & $\geq 512$ \\
\hline & & Niphates erecta (MA18-7) & $\geq 512$ & $\geq 512$ & $\geq 512$ & $\geq 512$ \\
\hline & & Niphates erecta (MA18-12) & $\geq 512$ & $\geq 512$ & $\geq 512$ & $\geq 512$ \\
\hline & & $\begin{array}{c}\text { Petrosiidae } \\
\text { Xestospongia } \text { muta (EP) }\end{array}$ & $\geq 512$ & $\geq 512$ & $\geq 512$ & $\geq 512$ \\
\hline & Homoscleropho-rida & $\begin{array}{c}\text { Plakinidae } \\
\text { Plakinastrella onkodes (E3) }\end{array}$ & $\geq 512$ & $\geq 512$ & $\geq 512$ & $\geq 512$ \\
\hline & \multirow{5}{*}{ Poecilosclerida } & $\begin{array}{c}\text { Crambeidae } \\
\text { Monanchora arbuscula (E35) }\end{array}$ & $\geq 512$ & $\geq 512$ & $\geq 512$ & 16 \\
\hline & & $\begin{array}{c}\text { Microcionidae } \\
\text { Clathria gomezae (EY18-11) }\end{array}$ & $\geq 512$ & $\geq 512$ & $\geq 512$ & $\geq 512$ \\
\hline & & Clathria virgultosa (E7-E34) & $\geq 512$ & $\geq 512$ & $\geq 512$ & $\geq 512$ \\
\hline & & $\begin{array}{c}\text { Mycalidae } \\
\text { Mycale laevis (MA18-1) }\end{array}$ & $\geq 512$ & $\geq 512$ & $\geq 512$ & $\geq 512$ \\
\hline & & Mycale laevis (MA18-5) & $\geq 512$ & $\geq 512$ & $\geq 512$ & $\geq 512$ \\
\hline & \multirow{3}{*}{ Scopalinida } & $\begin{array}{c}\text { Scopalinidae } \\
\text { Scopalina ruetzleri (MA18-5) }\end{array}$ & $\geq 512$ & $\geq 512$ & $\geq 512$ & $\geq 512$ \\
\hline & & Scopalina ruetzleri (E53) & $\geq 512$ & $\geq 512$ & $\geq 512$ & $\geq 512$ \\
\hline & & Scopalina ruetzleri (EY18-7) & $\geq 512$ & $\geq 512$ & $\geq 512$ & $\geq 512$ \\
\hline
\end{tabular}


Table 1. Cont

\begin{tabular}{|c|c|c|c|c|c|c|}
\hline Phylum & Order & Family, Species (Code) & $\begin{array}{l}\text { A. baumanni } \\
\text { ATCC } 17978\end{array}$ & $\begin{array}{l}\text { K. pneumonia } \\
\text { ATCC } 700603\end{array}$ & $\begin{array}{l}\text { P. aeruginosa } \\
\text { ATCC } 27823\end{array}$ & $\begin{array}{c}\text { S. aureus } \\
\text { ATCC } 29213\end{array}$ \\
\hline \multirow{12}{*}{ Porifera } & \multirow{2}{*}{ Suberitida } & $\begin{array}{c}\text { Halichondriidae } \\
\text { Halichondria melanadocia (E18-M1) }\end{array}$ & $\geq 512$ & $\geq 512$ & $\geq 512$ & $\geq 512$ \\
\hline & & $\begin{array}{c}\text { Suberitidae } \\
\text { Aaptos sp. (E38) }\end{array}$ & $\geq 512$ & $\geq 512$ & $\geq 512$ & $\geq 512$ \\
\hline & Tethyida & $\begin{array}{c}\text { Tethyidae } \\
\text { Tethya sp. (E20) }\end{array}$ & $\geq 512$ & $\geq 512$ & $\geq 512$ & $\geq 512$ \\
\hline & \multirow{2}{*}{ Tetractinellida } & $\begin{array}{c}\text { Geodiidae } \\
\text { Melophlus hajdui (E4) }\end{array}$ & $\geq 512$ & $\geq 512$ & $\geq 512$ & $\geq 512$ \\
\hline & & $\begin{array}{c}\text { Tetillidae } \\
\text { Cinachyrella kuekenthali (MA18-2) }\end{array}$ & $\geq 512$ & $\geq 512$ & $\geq 512$ & $\geq 512$ \\
\hline & \multirow{7}{*}{ Verongiida } & $\begin{array}{c}\text { Aplysinidae } \\
\text { Aiolochroia crassa (E50) }\end{array}$ & 64 & 128 & $>128$ & 32 \\
\hline & & Aiolochroia crassa (MA18-4) & 32 & 128 & 128 & 64 \\
\hline & & Aplysina cauliformis (E36) & $\geq 512$ & $\geq 512$ & $\geq 512$ & $\geq 512$ \\
\hline & & Aplysina fistularis (E46) & $\geq 512$ & $\geq 512$ & $\geq 512$ & $\geq 512$ \\
\hline & & Aplysina fulva (E42) & $\geq 512$ & $\geq 512$ & $\geq 512$ & $\geq 512$ \\
\hline & & Aplysina fulva (EY18-5) & $\geq 512$ & $\geq 512$ & $\geq 512$ & $\geq 512$ \\
\hline & & Aplysina muricyanna (E47) & $\geq 512$ & $\geq 512$ & $\geq 512$ & $\geq 512$ \\
\hline \multirow{2}{*}{\multicolumn{3}{|c|}{$\begin{array}{l}\text { Imipenem positive control } \\
\text { Vancomycin positive control }\end{array}$}} & 0.5 & 0.25 & 2 & nt \\
\hline & & & nt & nt & nt & 1 \\
\hline
\end{tabular}

nt: not tested. Bold numbers: high or intermediate MIC activities. 
The extract of $A$. citrina exhibited in vitro antibacterial activity similar to that of most antibiotics used in routine clinical practice, against both Gram-negative (MIC $8 \mathrm{mg} / \mathrm{L}$ ) and Gram-positive (MIC $0.5 \mathrm{mg} / \mathrm{L}$ ) pathogens. The extract of $H$. (Rhizoniera) curacaoensis also displayed high activity against $A$. baumannii (MIC of $4 \mathrm{mg} / \mathrm{L}$ ), a pathogen considered one of the opportunistic pathogens most threatening to global health and for which limited therapeutic options are available. The high genetic plasticity of this organism allows it to adapt quickly to unfavourable contexts and readily develop antibiotic resistance. This pathogen has been cited by some authors as a paradigm of multidrug-resistance [31]. Very few antimicrobials display higher in vitro activity against $A$. baumannii than this extract, e.g., imipenem and colistin, which are used as last-line antibiotics to treat severe infections (susceptibility breakpoint $\leq 2 \mathrm{mg} / \mathrm{L}$ ). The in vitro activity of $H$. (Rhizoniera) curacaoensis against $S$. aureus (MIC $4 \mathrm{mg} / \mathrm{L}$ ), was similar to the susceptibility breakpoints reported for antimicrobials used to treat this pathogen, such as vancomycin and linezolid (susceptibility breakpoints of $\leq 2$ and $\leq 4 \mathrm{mg} / \mathrm{L}$, respectively).

In addition to three of the extracts being active against all pathogenic species tested (A. citrina, A. compressa and H. (Rhizoniera) curacaoensis), the narrow-spectrum antibacterial activity displayed by another three extracts ( $M$. arbuscula, Dysidea sp. and A. sceptrum) against a maximum of two of the four bacteria tested) is also worth highlighting (Table 1). Most antibiotics used to treat bacterial infections are active against multiple species showing relevant benefits for use in clinical settings. However, the use of broad-spectrum antibiotics has two main drawbacks: (i) selection for resistant, pathogenic, and non-pathogenic bacteria leads to selection for resistance genes that decrease the usefulness of that antibiotic; and (ii) the use of broad-spectrum antibiotics has a deleterious effect on the host microbiome [32]. These are the main reasons why the FDA has approved fewer broad-spectrum antibiotics for use in the last two decades. Narrow-spectrum antimicrobials that do not select for cross-resistance and that decrease the possible damage to the host microbiome are urgently needed in the fight against infections caused by multidrug-resistant pathogens [33].

Furthermore, the antibacterial activity of the selected extracts is expected to be enhanced by isolation of the active compounds from these complex mixtures of compounds. Moreover, synergistic or antagonistic interactions between the different components of the extracts are also possible. All of these factors must be taken into consideration in order to initiate the processes of isolation and identification of the corresponding antibacterial agent(s).

As far as we are aware, there are no previous studies of the antibacterial activity of H. (Rhizoniera) curacaoensis or A. dilatata. However, antibacterial activities of the remaining six sponges have been reported. Thus, agelasidines with antifungal activity against Candida albicans have been extracted from A. citrina, one of the most promising crude extracts in the present study, and (-)-agelasidine $\mathrm{C}$ (MIC $0.5 \mathrm{mg} / \mathrm{L}$ ) was found to be the most active [34]. More recently, new pyrrole-imidazole alkaloids (denominated citrinamines) were isolated from the same species and were found to be able to inhibit the growth of the Gram-positive bacteria Micrococcus luteus and Mycobacterium phlei [35]. Inhibition of the growth of E. coli and Pseudomonas putida by extracts of this sponge has also been reported [36]. Furthermore, the presence of antibacterial activity in its extracts has also been reported in a study of the inhibition of growth of some non-pathogenic marine bacteria [37]. In the present study, we detected high activity of the extract from $A$. citrina (MIC $\leq 8 \mathrm{mg} / \mathrm{L}$ ) against the four pathogens tested.

Antimicrobial data on the sponge $A$. crassa has been published previously under the synonymous names of Ianthella basta and Ianthella ardis. Bastadin 1-6, hemibastadins 1-3 and hemibastadinols 1-3 were isolated from I. basta, all displaying antibacterial activity against Neisseria gonorrhoeae, Enterococcus faecalis, and S. aureus $[38,39]$. Recently, dibromohemibastadin- 1 , which showed a potent inhibition of biofilm formation of Paracoccus sp. 4M6 and P. aeruginosa PAO1 (at $10 \mu \mathrm{M}$ ) and quorum sensing inhibition of E. coli pSB401 (at 8-16 $\mu \mathrm{M}$ ), was isolated from the same species [40]. (-)-Aeroplysinin-1 and ianthelline were reported from I. ardis, both displaying antibacterial activity, the latter active against $S$. aureus [41,42]. 
Previous studies on $A$. compressa reported the isolation and identification of a new alkyl pyridine alkaloid, 8,8'-dienecyclostellettamine, which displayed a potent antibacterial activity against $E$. coli, P. aeruginosa, Cryptococcus neoformans, and methicillin-resistant $S$. aureus (MRSA), with $\mathrm{IC}_{50}$ values of $1.3,2.1,2.5$, and $0.25 \mathrm{mg} / \mathrm{L}$, respectively, as well as antifungal activity against C. albicans and Aspergillus fumigatus with $\mathrm{IC}_{50}$ values of 0.4 and $0.3 \mathrm{mg} / \mathrm{L}$, respectively [43]. Extracts from the same species were also active against marine strains [44] and E. faecalis [45].

Batzelladine L was reported from the sponge M. arbuscula and displays antifungal activity against Aspergillus flavus [46]. Previously, M. arbuscula was reported under the name of $M$. unguifera, describing the isolation of ptilomycalin A, batzelladines L, M, C, dehydrobatzelladine C, crambescidine 800, and $16 \beta$-hidroxycrambescidin 359, which showed antibactertial activity against MRSA, P. aeruginosa, and Mycobacterium intracellulare, with MIC values ranging between 0.31 and $20.0 \mathrm{mg} / \mathrm{L}$ [47].

The antimicrobial agent sceptrin has been isolated from A. sceptrum, yielding MICs of $15 \mathrm{mg} / \mathrm{L}$ for pathogenic species such as $S$. aureus, P. aeruginosa and C. albicans [48,49]. The antibacterial activity displayed by the extract of $A$. sceptrum against K. pneumoniae and P. aeruginosa (MICs of 256 and $64 \mathrm{mg} / \mathrm{L}$, respectively) in the present study is consistent with the aforementioned findings. Finally, the antibacterial activity of extracts of species belonging to the genus Dysidea has previously been reported; e.g., new sesquiterpenes isolated from the sponge Dysidea sp. displayed antibacterial activity against E. coli and S. aureus [50]. In the present study, Dysidea sp. extracts displayed antibacterial activity against $A$. baumannii and S. aureus (with MICs of 16 and $32 \mathrm{mg} / \mathrm{L}$, respectively).

\subsection{Antibacterial Activity and Bioassay-Guided Isolation of A. compressa Crude Extract}

The crude extract of $A$. compressa was submitted to a bioassay-guided fractionation because of the promising antibacterial activity detected (MIC of $32 \mathrm{mg} / \mathrm{L}$ for the four bacterial species tested in the microdilution assay). A combination of solid phase extraction (SPE) with an RP-18 cartridge (Merck KGaA) and reverse phase high performance liquid chromatography (RP-HPLC) was used to fractionate the organic extract and purify the active compounds. The bioassay-guided fractionation of the organic extract of $A$. compressa allowed us to separate fractions $\mathrm{R} 3$ and $\mathrm{R} 4$, which were eluted by SPE with, respectively, 1:1 and 1:2 mixtures of $\mathrm{H}_{2} \mathrm{O}$ and $\mathrm{CH}_{3} \mathrm{OH}$. Both fractions yielded the highest (and identical) MIC values (2-16 mg/L, Tables 2 and 3) for all pathogens tested. Taking into account that the ${ }^{1} \mathrm{H}$ NMR spectra of both fractions were very similar, suggesting that they contained similar compounds, and the fact that fraction R4 appeared to be purer than the R3 fraction, the former was chosen for further fractionation by RP-HPLC. The RP-HPLC chromatogram displayed a major peak (subfraction $\mathrm{R} 4 \mathrm{H} 2$ ) with a retention time of $16.8 \mathrm{~min}$ (Figure S1).

The ${ }^{1} \mathrm{H}-\mathrm{NMR}$ spectrum of subfraction R4H2 shows proton aromatic signals at $\delta_{\mathrm{H}} 8.88(\mathrm{~s}), 8.85(\mathrm{~d})$, $8.41(\mathrm{~d})$, and $8.02(\mathrm{dd})$, suggesting the presence of pyridine rings, proton olefinic signals at $\delta_{\mathrm{H}} 5.73(\mathrm{~m})$, $5.58(\mathrm{~m})$, and $4.60(\mathrm{t})$, indicating the presence of double bonds, and proton signals at $\delta_{\mathrm{H}} 3.68(\mathrm{~d})$, $2.20(\mathrm{~m}), 2.02(\mathrm{~m})$, and $1.39(\mathrm{~m})$ ppm, characteristic of carbon aliphatic chains (Figure S2).

The presence of a pyridine moiety and olefinic carbons was confirmed by the carbon resonances in the ${ }^{13} \mathrm{C}$-NMR spectrum, at $\delta_{\mathrm{C}} 146.5,145.2,144.5,143.5,135.3,129.0$, and 125.3, which also displayed the presence of carbon aliphatic chains with carbon resonances at $\delta_{C} 63.0,32.6,31.1,30.6,30.6,30.4$, $30.2,28.4$, and 27.3 ppm (Figure S3). Comparison of the 1D NMR data with previously reported data allowed us to identify an inseparable mixture of amphitoxins and halitoxins in subfraction $\mathrm{R} 4 \mathrm{H} 2$ (Figure 1) [51,52]. The structure of amphitoxin differs from that of halitoxin in that it has an additional carbon-carbon double bond in the alkyl chain that joins the pyridinium rings. Their similar structures make separation difficult and all attempts to separate this mixture were unsuccessful [46,53-55]. Subfraction R4H2 displayed higher antibacterial activity than fraction R4, yielding a MIC value of 2-4 mg/L for different strains of A. baumannii, K. pneumoniae, and P. aeruginosa and a MIC value of $1 \mathrm{mg} / \mathrm{L}$ for both strains of $S$. aureus (Tables 2 and 3). 
Table 2. MICs (mg/L) of the SPE fractions separated from the crude extract of $A$. compressa.

\begin{tabular}{ccccc}
\hline Fraction & $\begin{array}{c}\text { A. baumannii } \\
\text { ATCC 17978 }\end{array}$ & $\begin{array}{c}\text { K. pneumoniae } \\
\text { ATCC 700603 }\end{array}$ & $\begin{array}{c}\text { P. aeruginosa } \\
\text { ATCC 27823 }\end{array}$ & $\begin{array}{c}\text { S. aureus } \\
\text { ATCC 29213 }\end{array}$ \\
\hline R1 & 128 & 256 & 64 & $\mathrm{nt}^{*}$ \\
R2 & 128 & 256 & 256 & $\mathrm{Nt}$ \\
R3 & 8 & 16 & 16 & 2 \\
R4 & 8 & 16 & 16 & 2 \\
R5 & $>512$ & $>512$ & $>512$ & $\mathrm{Nt}$ \\
R6 & $>512$ & $>512$ & $>512$ & $\mathrm{Nt}$ \\
R7 & $>512$ & $>512$ & $>512$ & $\mathrm{Nt}$ \\
\hline \multicolumn{5}{r}{}
\end{tabular}

Table 3. MICs (mg/L) of the most active SPE fractions and HPLC subfraction R4H2 from A. compressa.

\begin{tabular}{ccccc}
\hline Bacterial Strain & & R3 & R4 & R4H2 \\
\hline \multirow{2}{*}{ A. baumannii } & ATCC 17978 & 8 & 8 & 4 \\
& ABRIM & 8 & 8 & 4 \\
\hline \multirow{2}{*}{ K. pneumoniae } & ATCC 700603 & 16 & 16 & 4 \\
& Kp3380 & 8 & 8 & 2 \\
\hline \multirow{2}{*}{ P. aeruginosa } & ATCC 27853 & 16 & 16 & 2 \\
& PAO1 & 16 & 16 & 4 \\
\hline \multirow{2}{*}{ S. aureus } & ATCC 29213 & 2 & 2 & 1 \\
& USA 300 & 1 & 1 & 1 \\
\hline
\end{tabular}

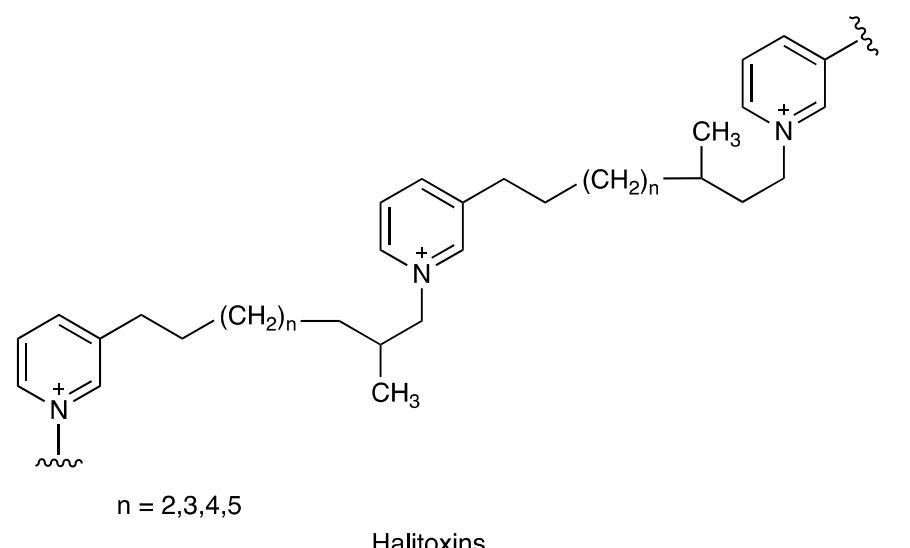

Halitoxins

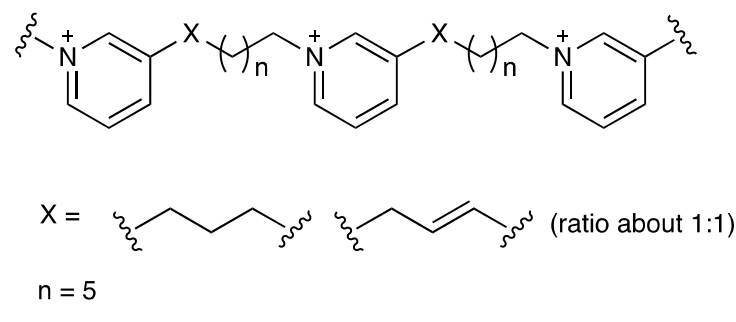

Amphitoxins

Figure 1. Substructure of the two closely related halitoxins and amphitoxins present as an inseparable mixture in the $\mathrm{R} 4 \mathrm{H} 2$ subfraction from $A$. compressa.

Sponges of the order Haplosclerida, to which Amphimedon compressa belongs, constitute well-known sources of alkylpyridine and alkylpiperidine alkaloids [40,56]. More specifically, halitoxins and amphitoxins are cyclic alkylpyridine oligomers of challenging separation and structural characterization 
due to their polycharged structures and high molecular weights [51-53]. They exert a multitude of biological actions. Regarding antibacterial activity, these compounds are able to inhibit bacterial attachment of Vibrio harveyi, a motile marine bacterium, but have not been reported to inhibit growth of the species [57]. Furthermore, these compounds have also been reported to show antibacterial activity against marine environmental isolates (MICs 4-256 mg/L) [55], as well as antifungal activity [47]. However, the antibacterial activity of halitoxins and amphitoxins detected in this study against the main multidrug-resistant human pathogens had not yet previously been observed.

\subsection{Antibacterial Activity and Bioassay-Guided Isolation of A. citrina Crude Extract}

The crude extract of $A$. citrina was submitted to a bioassay-guided fractionation because of the promising antibacterial activity detected (MIC of $8 \mathrm{mg} / \mathrm{L}$ against the Gram-negative and $0.5 \mathrm{mg} / \mathrm{L}$ against the Gram-positive bacteria species tested in the microdilution assay).

The crude extract was partitioned using the modified Kupchan procedure [58] to afford a very active dichloromethane fraction (FD), with MICs of 2-32 mg/L (Table 4), which was submitted to solid phase extraction (SPE) using an RP-18 cartridge to give seven subfractions (R1-R7). RP-HPLC purification of R2, which appeared as the most pure fraction (based on its ${ }^{1} \mathrm{H}$ NMR spectrum), with a MIC value of 4-8 $\mathrm{mg} / \mathrm{L}$ against $S$. aureus (Table 5), led to the isolation of a pure compound with a retention time of $35.2 \mathrm{~min}$ (see RP-HPLC chromatogram in Figure S4). Its high resolution electrospray mass spectrometry (HRESIMS) showed the $[\mathrm{M}+\mathrm{H}]^{+}$ion adduct at $m / z 422.3266$, and the ${ }^{1} \mathrm{H}$ and ${ }^{13} \mathrm{C}$ NMR spectral data (Figures S5-S7) and its optical rotation value matched with those of (-)-agelasine B (Figure 2), isolated from an unidentified sponge of the Agelas genus collected in the Okinawan sea $[59,60]$.

(-)-Agelasine B displays higher antibacterial activity against the two Gram-positive bacteria S. aureus strains ( $2 \mathrm{mg} / \mathrm{L}$ ) than fraction R2 (4 and $8 \mathrm{mg} / \mathrm{L}$ against ATCC 29213 and USA300 strains, respectively), as shown in Table 5 . However, (-)-agelasine B did not show significant activity against the Gram-negative bacteria (A. baumannii, K. pneumoniae, and P. aeruginosa). The identification of the remaining compounds responsible of the antibacterial activity against those bacteria are on the way.

Table 4. MICs (mg/L) of the liquid-liquid extraction fractions separated from the crude extract of A. citrina.

\begin{tabular}{ccccc}
\hline Fraction & $\begin{array}{c}\text { A. baumannii } \\
\text { ATCC 17978 }\end{array}$ & $\begin{array}{c}\text { K. pneumoniae } \\
\text { ATCC 700603 }\end{array}$ & $\begin{array}{c}\text { P. aeruginosa } \\
\text { ATCC 27823 }\end{array}$ & $\begin{array}{c}\text { S. aureus } \\
\text { ATCC 29213 }\end{array}$ \\
\hline WW & $>128$ & $>128$ & $>128$ & $>128$ \\
WB & $>128$ & $>128$ & $>128$ & $>128$ \\
FH & $>128$ & $>128$ & $>128$ & $>128$ \\
FM & 64 & 64 & 32 & 4 \\
FD & 16 & 32 & 32 & 2 \\
\hline
\end{tabular}

Table 5. MICs (mg/L) of the SPE fractions separated from the FD fraction of A. citrina and (-)-agelasine B isolated from subfraction R2.

\begin{tabular}{cccccccccc}
\hline Bacterial Strain & & R1 & R2 & R3 & R4 & R5 & R6 & R7 & (-)-agelasine B \\
\hline \multirow{2}{*}{ A. baumannii } & ATCC 17978 & $>64$ & 64 & 16 & $>64$ & 16 & $>64$ & 32 & $>128$ \\
& ABRIM & $>64$ & 64 & 16 & $>64$ & 16 & $>64$ & 32 & $>128$ \\
\hline \multirow{2}{*}{ K. pneumoniae } & ATCC 700603 & $>64$ & $>64$ & 32 & $>64$ & $>64$ & $>64$ & 32 & $>128$ \\
& Kp3380 & 64 & 64 & 8 & 64 & 16 & $>64$ & 16 & $>128$ \\
\hline \multirow{2}{*}{ P. aeruginosa } & ATCC 27853 & $>64$ & 64 & 16 & $>64$ & $>64$ & $>64$ & 32 & $>128$ \\
& PAO1 & $>64$ & 64 & 16 & $>64$ & $>64$ & $>64$ & 64 & $>128$ \\
\hline \multirow{2}{*}{ S. aureus } & ATCC 29213 & 8 & 4 & 0.5 & 8 & 2 & 8 & 2 & 2 \\
& USA 300 & 16 & 8 & 1 & 8 & 4 & 16 & 4 & 2 \\
\hline
\end{tabular}




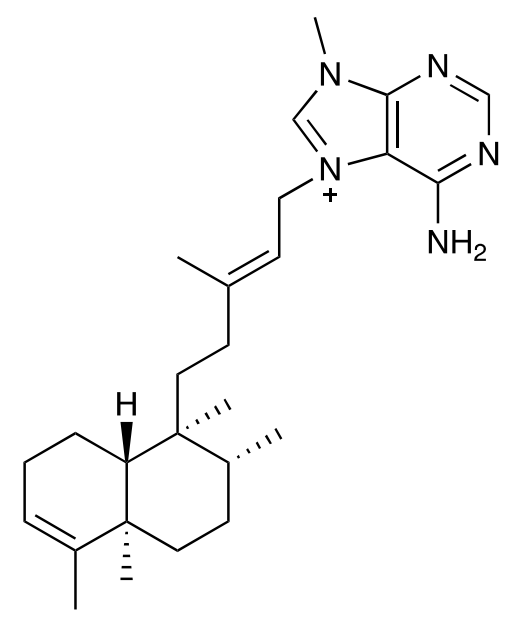

Figure 2. Structure of the (-)-agelasine B, isolated from Agelas citrina.

The antimicrobial activity (MIC) of (-)-agelasine B has been reported against Saccharomyces cerevisiae ATCC 188224 (10 mg/L) [61], Staphylococcus epidermidis 13889 (1.56 mg/L), E. faecalis 12964 (6.25 mg/L), E. faecium 12367 (3.13 mg/L), S. aureus 12732 (0.78 mg/L), MRSA (3.13 mg/L), Candida albicans IFO-1269 (>12.5 mg/L), and Cryptococcus neoformans TIMM-0354 (3.13 mg/L) [62], Mycobacterium smegmatis (3.13 mg/L) [63,64], M. bovis (6.25-12.5 mg/L) [64], and Proteusbacillus vulgaris (18.75 mg/L) [65]. However, (-)-agelasine B did not display antimicrobial activity against P. aeruginosa ATCC 15442, S. aureus ATCC 6538, Asperigillus niger (ATCC 9642) at $200 \mathrm{mg} / \mathrm{L} \mathrm{[62],} \mathrm{and} \mathrm{E.} \mathrm{coli} \mathrm{(>150} \mathrm{mg/L).}$ Its enantiomer, (+)-agelasine B, the isolation of which was reported in 2017, shows a potent antibacterial activity against clinical MRSA and methicillin-susceptible S. aureus (MSSA) [66].

\section{Material and Methods}

\subsection{General Experimental Procedures}

Optical rotations were measured on a JASCO DIP-1000 polarimeter, with a Na (589 nm) lamp and filter. ${ }^{1} \mathrm{H},{ }^{13} \mathrm{C}$, and $2 \mathrm{D}$ NMR spectra were recorded on a Bruker Avance 500 spectrometer at 500 and $125 \mathrm{MHz}$, respectively, using $\mathrm{CD}_{3} \mathrm{OD}$ and DMSO- $\mathrm{d}_{6}$. Low resolution electrospray mass spectrometry (LRESIMS) and high resolution electrospray mass spectrometry (HRESIMS) experiments were carried out on the Thermo LTQ Orbitrap Discovery system. HPLC separations were performed using an Agilent 1100 liquid chromatography system equipped with a solvent degasser, quaternary pump, and diode array detector (Agilent Technologies, Waldbronn, Germany) and a semipreparative reversed phase column Luna C18, $5 \mu \mathrm{m}, 100 \AA, 250 \times 10 \mathrm{~mm}$. Precoated silica gel plates (Merck, Kieselgel $60 \mathrm{~F} 254,0.25 \mathrm{~mm}$ ) were used for TLC analysis, and the spots were visualized under a UV light $(254 \mathrm{~nm})$ or by heating the plate pretreated with $\mathrm{H}_{2} \mathrm{SO} 4 / \mathrm{H}_{2} \mathrm{O} / \mathrm{AcOH}$ (1:4:20).

\subsection{Animal Collection and Identification}

Samples of animals were collected by snorkelling and SCUBA diving in different coastal zones of the Yucatan Peninsula, Mexico, during three different periods: September-December 2016, January-March 2017, and September 2018. The selected species were collected from two different regions: Mexican Caribbean (Cozumel Island, Rio Indio, Mahahual, and Bermejo, Quintana Roo) and Campeche Bank (Alacranes Reef and Progreso, Yucatan) in areas with high biological diversity, such as coral reefs, islands, and mangrove forests (Figure 3). 


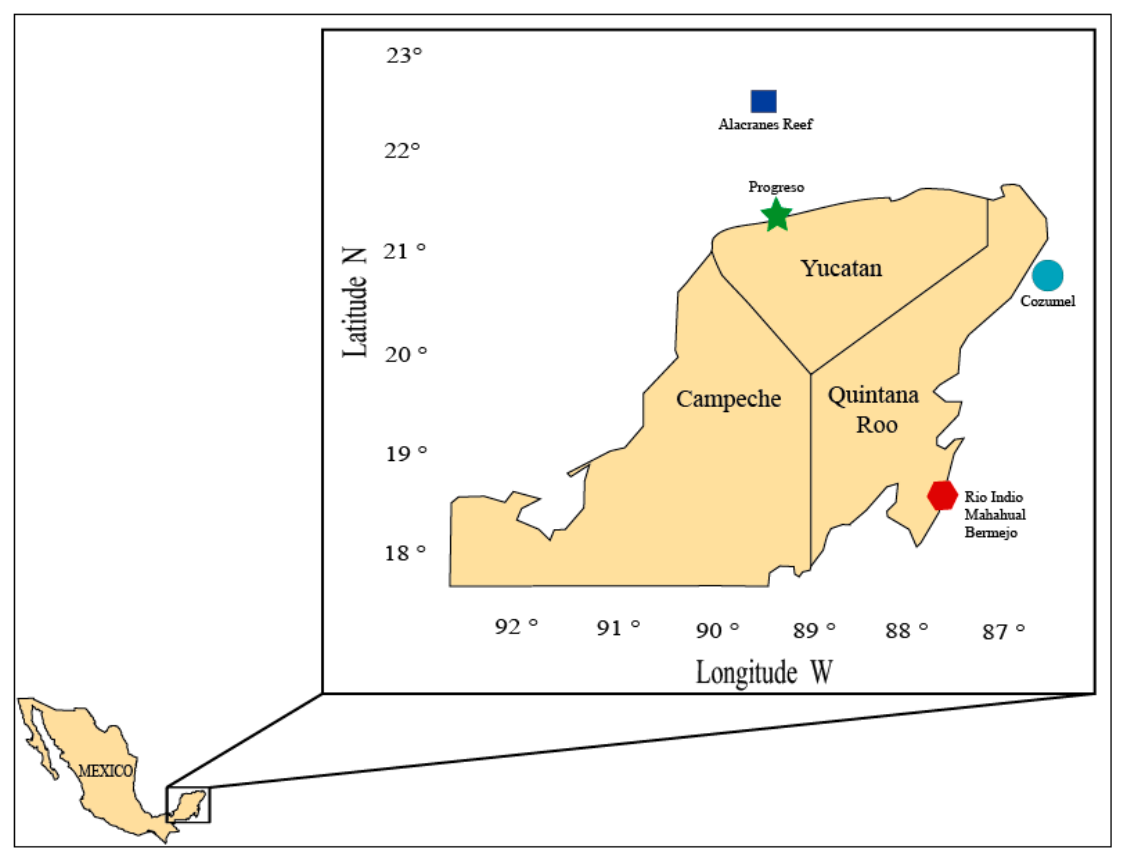

Figure 3. Sites of collection of marine organisms in the Yucatan Peninsula, Mexico.

The samples were labelled with a code according to the collection site, stored in plastic bags, and chilled on ice during transport to the laboratory. Voucher specimens of sponges were deposited in the Phylum Porifera Gerardo Green National Collection of the Institute of Marine Sciences and Limnology (ICMyL) at the National Autonomous University of Mexico (UNAM), Mexico City, while voucher specimens of ascidians were deposited in the Marine Biology Collection at the Autonomous University of Yucatan (UADY) in Yucatan, Mexico.

The sponges were identified at the ICMyL-UNAM (Mexico), while the ascidians were identified at the University of Vigo (Spain) and the Autonomous University of Yucatan (Mexico). Taxonomic information, collection sites, and previous antimicrobial activity records of the species or genus studied of the 64 selected marine organisms, are shown in Table 6. 
Table 6. Taxonomic information, voucher numbers, site of collection, and previously reported antibacterial activity for the species under study, including synonymised names for the eight species that showed active.

\begin{tabular}{|c|c|c|c|c|}
\hline Family & Species, (Code) & Site & Reported Antibacterial Activity & References \\
\hline \multicolumn{5}{|c|}{$\begin{array}{l}\text { Phylum: Chordata } \\
\text { Order: Aplousobranchia }\end{array}$} \\
\hline Clavelinidae & Clavelina sp. (T18-M1) & Progreso, Yucatan (Mangrove) & $\begin{array}{l}\text { Example of species of this genus: C. pictus. Stereoisomers of piclavins A2 to A4 displayed low } \\
\text { activity against Gram-positive bacteria (S.aureus, B. cereus and C. michiganensis). }\end{array}$ & [67] \\
\hline \multirow{5}{*}{ Didemnidae } & Didemnum perlucidum (E8-2) & Rio Indio, Quintana Roo & Low activity against $S$. aureus, and not active against $E$. coli and $P$. aeruginosa. & [68] \\
\hline & Didemnum sp. (T18-M4) & Progreso, Yucatan (Mangrove) & \multirow{2}{*}{$\begin{array}{l}\text { Example of species of this genus: } \\
\text { Antimicrobial activity of an unidentified Didemnum species against E. faecalis, S. aureus, } \\
\text { S. typhimurium, S. marcescens and P. aeruginosa. }\end{array}$} & \multirow[t]{2}{*}{ [69] } \\
\hline & Didemnum sp. (E01) & Bermejo, Quintana Roo & & \\
\hline & Trididemnum solidum (E7-2) & Rio Indio, Quintana Roo & No previous reports for this species. & \\
\hline & Polysyncraton sp. (EY18-8) & Progreso, Yucatan & No previous reports for this genus. & \\
\hline \multirow{2}{*}{ Polycitoridae } & Eudistoma amanitum (RIO18-T1) & Río Indio, Quintana Roo & No previous reports for this genus. & \\
\hline & Eudistoma sp. (TY18-2) & Progreso, Yucatan & No previous reports for this genus. & \\
\hline Polyclinidae & Polyclinum sp. (T18-M5) & Progreso, Yucatan (Mangrove) & $\begin{array}{l}\text { The extract of a Polyclinum sp. yielded MICs of }>1000 \mathrm{mg} / \mathrm{L} \text { against S. aureus, E. coli and } \\
\text { P. aeruginosa. }\end{array}$ & [68] \\
\hline \multicolumn{5}{|c|}{ Order: Phlebobranchia } \\
\hline Ascidiidae & Phallusia nigra (TY18-1) & Progreso, Yucatan & $\begin{array}{c}\text { Low antimicrobial activity against B. subtilis, S. aureus, E. aerogenes, E. coli, K. pneumoniae, } \\
\text { P. aeruginosa, S. paratyphii, S. typhii and V. cholera. }\end{array}$ & [70] \\
\hline Perophoridae & Ecteinascidia sp. (T18-M2) & Progreso, Yucatan (Mangrove) & No previous reports for this genus. & \\
\hline \multicolumn{5}{|c|}{ Order: Stolidobranchia } \\
\hline Molgulidae & Molgula sp. (T18-M6) & Progreso, Yucatan (Mangrove) & No previous reports for this genus. & \\
\hline Styelidae & Polycarpa sp. (E41) & Alacranes Reef, Yucatan & No previous reports for this genus. & \\
\hline \multicolumn{5}{|c|}{$\begin{array}{l}\text { Phylum: Porifera } \\
\text { Order: Agelasida }\end{array}$} \\
\hline \multirow{5}{*}{ Agelasidae } & Agelas citrina (CZE56) & Cozumel, Quintana Roo & $\begin{array}{l}\text { Antimicrobial activity against } E \text {. coli and inhibition of its quorum sensing. No antimicrobial } \\
\text { activity against } C \text {. violaceum. Inhibition of quorum sensing at high concentrations. }\end{array}$ & [37] \\
\hline & Agelas clathrodes (E27-2) & Cozumel, Quintana Roo & \multirow{2}{*}{$\begin{array}{c}\text { Clathrodin did not display antimicrobial activity against E. faecalis, S. aureus and E. col, but } \\
\text { displayed low antifungal activity against C. albicans. }\end{array}$} & \multirow{2}{*}{ [71] } \\
\hline & Agelas clathrodes (MA18-10) & Mahahual, Quintana Roo & & \\
\hline & Agelas dilatate (E25-1) & Cozumel, Quintana Roo & No previous reports for this species. & \\
\hline & Agelas sceptrum (E26-2) & Cozumel, Quintana Roo & Sceptrin displayed antimicrobial activity against $S$.aureus, B. subtilis and P. aeruginosa. & {$[49,72]$} \\
\hline
\end{tabular}


Table 6. Cont

\begin{tabular}{|c|c|c|c|c|}
\hline Family & Species, (Code) & Site & Reported Antibacterial Activity & References \\
\hline \multicolumn{5}{|c|}{ Order: Axinellida } \\
\hline Heteroxyidae & Myrmekioderma gyroderma (CZE18) & Cozumel, Quintana Roo & No previous reports for this species. & \\
\hline \multirow{2}{*}{ Raspailiidae } & Ectyoplasia ferox (MA18-9) & Mahahual, Quintana Roo & No previous reports for this species. & \\
\hline & Ectyoplasia sp. (MA18-13) & Mahahual, Quintana Roo & No previous reports for this genus. & \\
\hline \multicolumn{5}{|c|}{ Order: Chondrillida } \\
\hline \multirow{2}{*}{ Chondrillidae } & $\begin{array}{l}\text { Chondrilla caribensis } f \text {. hermatypica } \\
\text { (MA18-6) }\end{array}$ & Mahahual, Quintana Roo & No inhibition of S. aureus, S. epidermidis or E. coli growth. & [73] \\
\hline & Chondrilla sp. (RIO18-1) & Río Indio, Quintana Roo & No previous reports for this genus. & \\
\hline \multicolumn{5}{|c|}{ Order: Clathrinida } \\
\hline Clathrinidae & Clathrina sp. (EY18-10) & Progreso, Yucatan & No previous reports for this genus. & \\
\hline Leucettidae & Leucetta floridana (E2-2) & Bermejo, Quintana Roo & No previous reports for this species. & \\
\hline \multicolumn{5}{|c|}{ Order: Clionaida } \\
\hline \multirow{2}{*}{ Clionaidae } & Cliona delitrix (EY18-1) & Progreso, Yucatan & Quorum sensing inhibition in E.coli. & [37] \\
\hline & Cliona varians (EY18-3) & Progreso, Yucatan & No observed antibacterial activity against $E$. coli or C. violaceum. & [37] \\
\hline \multicolumn{5}{|c|}{ Order: Dictyoceratida } \\
\hline Dysideidae & Dysidea sp. (EY18-12) & Progreso, Yucatan & & \\
\hline \multirow{4}{*}{ Irciniidae } & Ircinia felix (E9-2) & Rio Indio, Quintana Roo & \multirow{2}{*}{$\begin{array}{l}\text { Quorum sensing inhibition in C. violaceum. No effects on bacterial growth observed for this species. } \\
\text { Antibacterial activity against B. subtilis. }\end{array}$} & \multirow{2}{*}[37,74]{} \\
\hline & Ircinia felix (MA18-11) & Mahahual, Quintana Roo & & \\
\hline & Ircinia strobilina (E24-2) & Cozumel, Quintana Roo & \multirow{2}{*}{ Antibacterial activity against $B$. subtilis. No inhibition of $E$. coli growth. } & \multirow{2}{*}{ [74] } \\
\hline & Ircinia strobilina (E52) & Bermejo, Quintana Roo & & \\
\hline Spongiidae & Spongia tubulifera (E11-2) & Rio Indio, Quintana Roo & No previous reports for this species. & \\
\hline \multicolumn{5}{|c|}{ Order: Haplosclerida } \\
\hline \multirow{3}{*}{ Callyspongiidae } & Callyspongia longissima (E28) & Alacranes Reef, Yucatan & No previous reports for this species. & \\
\hline & Callyspongia plicifera (E31) & Alacranes Reef, Yucatan & Antibacterial activity against E. coli. & [74] \\
\hline & Callyspongia vaginalis (E16) & Cozumel, Quintana Roo & Antibacterial activity against $B$. subtilis & [74] \\
\hline Chalinidae & $\begin{array}{l}\text { Haliclona (Rhizoniera) } \\
\text { curacaoensis (EY18-4) }\end{array}$ & Progreso, Yucatan & No previous reports for this species. & \\
\hline
\end{tabular}


Table 6. Cont

\begin{tabular}{|c|c|c|c|c|}
\hline Family & Species, (Code) & Site & Reported Antibacterial Activity & References \\
\hline \multirow{5}{*}{ Niphatidae } & Amphimedon compressa (E29) & Alacranes Reef, Yucatan & $\begin{array}{l}\text { Antibacterial activity of extracts against marine bacteria strains, E. faecalis, } P \text {. aeruginosa and } E \text {. coli. } \\
8,8^{\prime} \text {-dienecyclostellettamine showed a potent antibacterial activity against } E \text {. coli, } P \text {. aeruginos } \\
\text { and MRSA with } \mathrm{IC}_{50} \text { values of } 1.3,2.1,0.25 \mathrm{mg} / \mathrm{L} \text { respectively. }\end{array}$ & [43-46] \\
\hline & Niphates digitalis (E15) & Cozumel, Quintana Roo & No previous reports for this species. & \\
\hline & Niphates erecta (E49) & Alacranes Reef, Yucatan & \multirow{3}{*}{ No previous reports for this species. } & \\
\hline & Niphates erecta (MA18-7) & Mahahual, Quintana Roo & & \\
\hline & Niphates erecta (MA18-12) & Mahahual, Quintana Roo & & \\
\hline Petrosiidae & Xestospongia muta (EP) & Alacranes Reef, Yucatan & No growth or quorum sensing inhibition of E. coli or C. violaceum. & [37] \\
\hline \multicolumn{5}{|c|}{ Order: Homosclerophorida } \\
\hline Plakinidae & Plakinastrella onkodes (E3) & Bermejo, Quintana Roo & No previous reports for this species. & \\
\hline \multicolumn{5}{|c|}{ Order: Poecilosclerida } \\
\hline Crambeidae & $\begin{array}{l}\text { Monanchora arbuscula } \text { (E35) } \\
\text { Synonymised names: } \\
\text { M. unguifera }\end{array}$ & Alacranes Reef, Yucatan & $\begin{array}{c}\text { Ptilomycalin A, batzelladines L, M, C, dehydrobatzelladine C, crambescidine } 800 \text { and } \\
\text { 16ß-hidroxycrambescidin } 359 \text { were isolated of this species and showed MIC of between } \\
0.31-20.0 \mathrm{mg} / \mathrm{L} \text { against S. aureus, methicillin-resistant S. aureus (MRSA), P. aeruginosa and } \\
\text { M. intracellulare. }\end{array}$ & [47] \\
\hline \multirow[t]{2}{*}{ Microcionidae } & Clathria gomezae (EY18-11) & Progreso, Yucatan & No previous reports for this species. & \\
\hline & Clathria virgultosa (E7-E34) & Alacranes Reef, Yucatan & No previous reports for this species. & \\
\hline \multirow{2}{*}{ Mycalidae } & Mycale laevis (MA18-1) & Mahahual, Quintana Roo & \multirow{2}{*}{ No previous reports for this species. } & \\
\hline & Mycale laevis (MA18-5) & Mahahual, Quintana Roo & & \\
\hline \multicolumn{5}{|c|}{ Order: Scopalinida } \\
\hline \multirow{3}{*}{ Scopalinidae } & Scopalina ruetzleri (DNY) & Rio Indio, Quintana Roo & \multirow{3}{*}{ No previous reports for this species. } & \\
\hline & Scopalina ruetzleri (E53) & Cozumel, Quintana Roo & & \\
\hline & Scopalina ruetzleri (EY18-7) & Progreso, Yucatan & & \\
\hline \multicolumn{5}{|c|}{ Order: Suberitida } \\
\hline Halichondriidae & $\begin{array}{l}\text { Halichondria melanadocia } \\
\text { (E18-M1) }\end{array}$ & Progreso, Yucatan (Mangrove) & No previous reports for this species. & \\
\hline Suberitidae & Aaptos sp. (E38) & Alacranes Reef, Yucatan & No previous reports for this species. & \\
\hline \multicolumn{5}{|c|}{ Order: Tethyida } \\
\hline Tethyidae & Tethya sp. (E20) & Cozumel, Quintana Roo & No previous reports for this species. & \\
\hline
\end{tabular}


Table 6. Cont

\begin{tabular}{|c|c|c|c|c|}
\hline Family & Species, (Code) & Site & Reported Antibacterial Activity & References \\
\hline \multicolumn{5}{|c|}{ Order: Tetractinellida } \\
\hline Geodiidae & Melophlus hajdui (E4) & Bermejo, Quintana Roo & Antibacterial activity against Mycobacterium sp. & [75] \\
\hline Tetillidae & Cinachyrella kuekenthali (MA18-2) & Mahahual, Quintana Roo & $\begin{array}{l}\text { Antibacterial activity of aqueous and ethanolic extracts against different species of the genus } \\
\qquad \text { Staphylococcus sp. }\end{array}$ & [76] \\
\hline \multicolumn{5}{|c|}{ Order: Verongiida } \\
\hline \multirow{6}{*}{ Aplysinidae } & $\begin{array}{l}\text { Aiolochroia crassa (E50) } \\
\text { Synonymised names: } \\
\text { Pseudoceratina crassa, Ianthella } \\
\text { basta and Ianthella ardis }\end{array}$ & Alacranes Reef, Yucatan & $\begin{array}{l}\text { Antibacterial activity of extracts against marine bacteria strains and B. subtilis with MIC of } 0.4 \mathrm{mg} / \mathrm{L} \text {. } \\
\text { Bastadin 1-6, hemibastadins 1-3 and hemibastadinols } 1-3 \text { showed antibacterial activity againts } \\
\text { Neisseria gonorrhoeae, E. faecalis and S. aureus. } \\
\text { Dibromohemibastadin-1 showed potent antibacterial activity against the biofilm formation of } \\
\text { Paracoccus sp. 4M6 and P. aeruginosa PAO1 }(10 \mu \mathrm{M}) \text { and quorum sensing inhibition of E. coli pSB401 } \\
(8-16 \mu \mathrm{M}) \text { assays. } \\
\text { (-)-Aeroplysinin-1 showed antibacterial activity. } \\
\text { Ianthelline showed antibacterial activity against } S \text {. aureus. }\end{array}$ & {$[38-42,44,74]$} \\
\hline & Aplysina cauliformis (E36) & Alacranes Reef, Yucatan & Antibacterial activity against $M$. tuberculosis $\mathrm{H} 37 \mathrm{Rv}$. & [77] \\
\hline & Aplysina fistularis (E46) & Alacranes Reef, Yucatan & No previous reports for this species. & \\
\hline & Aplysina fulva (E42) & Alacranes Reef, Yucatan & \multirow{2}{*}{ Antibacterial activity against marine bacteria strains. } & \multirow[t]{2}{*}{ [44] } \\
\hline & Aplysina fulva (EY18-5) & Progreso, Yucatan & & \\
\hline & Aplysina muricyanna (E47) & Alacranes Reef, Yucatan & No previous reports for this species. & \\
\hline
\end{tabular}




\subsection{Preparation of the Organic Extracts}

Tissue slices from each species were exhaustively extracted with a mixture of dichloromethanemethanol (1:1), i.e., three times each with $500 \mathrm{~mL}$ of solvent $\left(1.5 \mathrm{~L}\right.$ total volume) at $25^{\circ} \mathrm{C}$ for $24 \mathrm{~h}$. The solvent was filtered and then removed under vacuum at $40{ }^{\circ} \mathrm{C}$ with a rotatory evaporator. The extracts were stored at $-20^{\circ} \mathrm{C}$ in tightly sealed glass vials.

\subsection{Bioassay-Guided Isolation of the A. compressa Crude Extract}

Whole bodies of $A$. compressa (wet weight, $509.2 \mathrm{~g}$; dry weight, $64.0 \mathrm{~g}$ ) were sliced and exhaustively extracted, as previously described, to yield $8.3 \mathrm{~g}$ of a crude residue. Fractionation of $8.2 \mathrm{~g}$ of the residue by solid phase extraction (SPE), using a stepped gradient from $\mathrm{H}_{2} \mathrm{O}$ to $\mathrm{CH}_{3} \mathrm{OH}$ and then $\mathrm{CH}_{2} \mathrm{Cl}_{2}\left(\mathrm{H}_{2} \mathrm{O}\right.$ (100\%), $\mathrm{H}_{2} \mathrm{O} / \mathrm{CH}_{3} \mathrm{OH}\left(2: 1,1: 1\right.$, and 1:2), $\mathrm{CH}_{3} \mathrm{OH}(100 \%), \mathrm{CH}_{3} \mathrm{OH} / \mathrm{CH}_{2} \mathrm{Cl}_{2}$ (1:1), and $\mathrm{CH}_{2} \mathrm{Cl}_{2} 100 \%$ ), yielded seven fractions (R1-R7). The fractions were concentrated under reduced pressure producing the following weights: R1: 6.7 g, R2: 213.3 mg; R3: 71.6 mg; R4: 74.7 mg; R5: 931.4 mg; R6: 192.3 mg; R7: $11.1 \mathrm{mg}$. In the evaluation of the fractions in the both microdilution assays (Tables 2 and 3), fractions R3 and R4 displayed antibacterial activity. Part of the most active fraction R4 (50 mg) was further fractioned by HPLC, the mobile phase consisted of: (A) $\mathrm{H}_{2} \mathrm{O}$ with $0.04 \%$ of trifluroacetic acid; (B) $\mathrm{CH}_{3} \mathrm{OH}$ with $0.04 \%$ of trifluoracetic acid at a flow rate of $2.0 \mathrm{~mL} / \mathrm{min}$. A combination of gradient and isocratic elution was used, starting with $90 \% \mathrm{~A}$ and $10 \% \mathrm{~B}$, changing to $67 \%$ of $\mathrm{B}$ in $10 \mathrm{~min}$, followed by $5 \mathrm{~min}$ isocratic at $67 \%$ of B, 2 min gradient from $67 \%$ to $75 \%$ of B, 23 min of isocratic at $75 \%$ of $\mathrm{B}$, and finally, changing to $100 \%$ of $\mathrm{B}$ in $5 \mathrm{~min}$. A major peak, subfraction $\mathrm{R} 4 \mathrm{H} 2$, eluted with a retention time of $16.8 \mathrm{~min}$, was collected and concentrated under reduced pressure to produce $8.0 \mathrm{mg}$ of yellow solid which was identified by NMR analysis as a mixture of alkylpyridine oligomers halitoxins and amphitoxins. Bioassay-guided fractionation was performed using an antibacterial activity assay against the four bacterial pathogens, as detailed in below.

\subsection{Bioassay-Guided Isolation of the A. citrina Crude Extract}

Sliced bodies of $A$. citrina (wet weight, $729.6 \mathrm{~g}$; dry weight, $375.3 \mathrm{~g}$ ) were exhaustively extracted, as previously described, to give $6.1 \mathrm{~g}$ of a crude residue. Liquid-liquid fractionation of $6.0 \mathrm{~g}$ between $\mathrm{H}_{2} \mathrm{O} / \mathrm{CH}_{2} \mathrm{Cl}_{2}(1: 1 \mathrm{v} / \mathrm{v})$ gave aqueous and an organic phases. The aqueous phase was extracted with n-butanol $(200 \mathrm{~mL})$ to yield $217.0 \mathrm{mg}$ of the final aqueous fraction $(\mathrm{WW})$ and $756.0 \mathrm{mg}$ of the $n$-butanol fraction (WB), after removal the solvents under reduced pressure. The organic phase was concentrated under reduced pressure and was further partitioned between $10 \%$ aqueous $\mathrm{CH}_{3} \mathrm{OH}(400 \mathrm{~mL})$ and hexane $(2 \times 400 \mathrm{~mL})$ to give, after removing the solvent under reduced pressure, $672.2 \mathrm{mg}$ of the hexane fraction (FH). The $\mathrm{H}_{2} \mathrm{O}$ content $(\% \mathrm{v} / \mathrm{v})$ of the methanolic fraction was adjusted to $50 \%$ aqueous $\mathrm{CH}_{3} \mathrm{OH}$, and the mixture was extracted with $\mathrm{CH}_{2} \mathrm{Cl}_{2}(100 \mathrm{~mL})$ to afford, after removing the solvent under reduced pressure, $3.6 \mathrm{~g}$ of the $\mathrm{CH}_{2} \mathrm{Cl}_{2}$ fraction (FD) and $755.8 \mathrm{mg}$ of the remaining aqueous methanolic fraction (FM). The $\mathrm{CH}_{2} \mathrm{Cl}_{2}$ and aqueous methanolic fractions displayed antibacterial activity in the microdilution assays (Table 4). Part of the $\mathrm{CH}_{2} \mathrm{Cl}_{2}$ fraction (3.6 g) was subjected to a solid phase extraction (SPE), using a stepped gradient from $\mathrm{H}_{2} \mathrm{O}$ to $\mathrm{CH}_{3} \mathrm{OH}$ and then $\mathrm{CH}_{2} \mathrm{Cl}_{2}\left(\mathrm{H}_{2} \mathrm{O}\right.$ (100\%), $\mathrm{H}_{2} \mathrm{O} / \mathrm{CH}_{3} \mathrm{OH}\left(2: 1,1: 1\right.$, and 1:2), $\mathrm{CH}_{3} \mathrm{OH}(100 \%), \mathrm{CH}_{3} \mathrm{OH} / \mathrm{CH}_{2} \mathrm{Cl}_{2}$ (1:1), and $\mathrm{CH}_{2} \mathrm{Cl}_{2} 100 \%$ ), to yield, after removing the solvents under reduced pressure, seven fractions: R1 (2.5 g); R2 (181.3 mg); R3 (191.3 mg); R4 (391.1 mg); R5 (315.9 mg); R6 (5.3 mg); and R7 (11.5 mg). All of them displayed antibacterial activity against $S$. aureus (Table 5$)$. The active fraction $\mathrm{R} 2(181.3 \mathrm{mg})$ was further fractioned by HPLC. The mobile phase consisted of (A) $\mathrm{H}_{2} \mathrm{O}$ with $0.04 \%$ of trifluroacetic acid, and (B) $\mathrm{CH}_{3} \mathrm{OH}$ with $0.04 \%$ of trifluoracetic acid, and the analysis were run at a flow rate of $2.0 \mathrm{~mL} / \mathrm{min}$. A combination of gradient and isocratic elution was used, starting with $30 \% \mathrm{~B}$, increasing to $100 \%$ of B in $30 \mathrm{~min}$, followed by $10 \mathrm{~min}$ isocratic at $100 \%$ of $\mathrm{B}$. A major peak, subfraction $\mathrm{R} 2 \mathrm{H} 13$, eluted with a retention time of $35.2 \mathrm{~min}$, was collected and concentrated under reduced pressure to produce $3.0 \mathrm{mg}$ of white solid which was identified by NMR and MS analysis as (-)-agelasine B. Bioassay-guided fractionation 
was performed using an antibacterial activity assay against the four bacterial pathogens, as detailed in below.

(-)-agelasine B. $[\alpha]_{\mathrm{D}}^{25}-11.0\left(c\right.$ 0.17, MeOH); ${ }^{1} \mathrm{H}$ and ${ }^{13} \mathrm{C}$ NMR spectra see SM; (+)-HRESIMS $m / z 422.3266$ $[\mathrm{M}+\mathrm{H}]^{+}$, (calcd. for $\mathrm{C}_{26} \mathrm{H}_{40} \mathrm{~N}_{5}, m / z$ 422.3284).

\subsection{Antimicrobial Activity Assays}

\subsubsection{Bacterial Strains and Culture Preparation}

The bacterial strains used to study the antibacterial activity of the crude extracts (Tables S1 and S2 in the SI) were the Gram-negative pathogens A. baumannii (strain ATCC 17978), P. aeruginosa (strain ATCC 27853), and K. pneumoniae (strain ATCC 700603), and the Gram-positive pathogen S. aureus (strains ATCC 29213). For bioassay-guided fractionation of $A$. compressa, the following bacterial strains were also used: A. baumannii ABRIM, K. pneumoniae Kp3380, P. aeruginosa PAO1, and S. aureus USA 300 LAC. Strain PAO1 is a reference strain, commonly used in research, and the other three strains are clinical isolates collected from samples from the Complexo Hospitalario Universitario A Coruña (CHUAC) hospital in Spain.

Gram-negative and Gram-positive strains were routinely grown or maintained in Luria-Bertani (LB), and in Trypticase soya broth (TSB) media, respectively, supplemented with $2 \%$ agar or the antibiotic ampicillin (30 mg/L), when needed. All strains were grown at $37^{\circ} \mathrm{C}$ and stored in $10 \%$ glycerol at $-80^{\circ} \mathrm{C}$.

\subsubsection{Microdilution Method: Minimum Inhibitory Concentration}

The minimum inhibitory concentrations (MICs) were determined by the broth microdilution method (CLSI, 2012). Briefly, the bacterial strains were cultured overnight at $37^{\circ} \mathrm{C}$ in Mueller Hinton II agar plates (Becton Dickinson) and the turbidity of the bacterial suspensions was standardized at 0.5 on the McFarland scale to establish the inocula. The crude extracts of the test samples were dissolved in dimethylsulfoxide (DMSO). Two-fold serial dilutions of the extracts in Mueller Hinton II broth medium (Sigma) were carried out in 96-wells microplates, to produce a range of extract concentrations of $0.5-256 \mathrm{mg} / \mathrm{L}$. DMSO was present at a maximum concentration of $2.5 \% \mathrm{v} / \mathrm{v}$ in the well containing the highest concentration of extract $(256 \mathrm{mg} / \mathrm{L})$. One well in each row contained growth media and bacterial suspension and was used as a positive growth control. Another well, containing medium only, was used as a negative control. Solvent controls of DMSO and growth medium were included to determine whether the concentrations used interfered with bacterial growth. The MIC was evaluated after incubation $20-24 \mathrm{~h}$ to $37^{\circ} \mathrm{C}$ and was established as the lowest concentration of the compound at which the bacterial strains did not grow. All extracts were tested in triplicate.

MIC assays were also performed with ampicillin, cefoxitin, cefotaxime, ceftazidime, cefepime, imipenem, ciprofloxacin, and tobramycin against A. baumannii, K. pneumoniae, and P. aeruginosa strains, and with cefoxitin, oxacillin, erythromycin, clindamycin, and vancomycin against $S$. aureus strains (Table S2).

\section{Conclusions}

There is an urgent need for successful treatments for patients with infections caused by multidrug-resistant bacteria. Developing new antibiotics that contribute to fighting against antibacterial resistance is one of the main current objectives in public health.

A total of 64 marine organisms, 51 sponges (Porifera), and 13 ascidians (Chordata), selected on the basis of chemotaxonomic criteria, were collected on the coast of the Yucatan Peninsula in Mexico and organic extracts were obtained from each. One aliquot of each extract was submitted to in vitro antibacterial screening against four species of multidrug-resistant (MDR) bacterial pathogens: the Gram-negative A. baumannii, K. pneumoniae, and P. aeruginosa, and the Gram-positive S. aureus. MICs (determined by microdilution assay) indicated antibacterial activity of nine extracts from 
eight sponges: A. citrina, A. dilatata, A. sceptrum, A. crassa (collected from two different locations: Mahahual, Quintana Roo and Alacranes Reef), A. compressa, Dysidea sp., M. arbuscula, and H. (Rhizoniera) curacaoensis. Some of the extracts showed similar MIC values to known antibiotics, such as penicillins and aminoglycosides. Isolation of pure compounds from the complex mixtures constituting the extracts is expected to yield greater antibacterial activity. Preliminary studies on two of the active sponge extracts were performed using a bioassay-guided fractionation methodology. Thus, the active extract from the sponge $A$. compressa yielded an unseparable mixture of halitoxins and amphitoxins which displayed notable antibacterial in vitro activity against all four pathogenic bacteria. This is the first report of the antimicrobial activity of halitoxins and amphitoxins against major multidrug-resistant human pathogens. On the other hand, (-)-agelasine B was isolated from the sponge A. citrina as the major component responsible of the potent antibacterial activity of its extract against the Gram-positive S. aureus. The inactivity (-)-agelasine B against the three Gram-negative bacteria tested (A. baumannii, K. pneumoniae, and P. aeruginosa) was indicative of the presence of additional active compounds not isolated yet.

These organisms will be subjected to further detailed analysis to isolate biologically active molecules in the search for new compounds. Furthermore, the promising antibacterial activities detected in this study indicate the coast of Yucatan Peninsula as a potential source of a great variety of marine organisms worthy of further research. This type of study can serve as a basis for the development of new antibacterial agents effective against the principal multidrug-resistant bacterial pathogens for which the therapeutic options are increasingly scarce. This study constitutes the first report of antibacterial activity for a wide collection of sponges and ascidians collected on the coast of the Yucatan Peninsula.

Supplementary Materials: The following are available online at http://www.mdpi.com/1660-3397/18/7/369/s1, Figures S1-S7: Chromatograms, NMR and MS of fraction R4 from Amphimedon compressa and (-)-agelasine B from Agelas citrina. Table S1: Description of bacterial type strains used. Table S2: MICs of antibiotics against bacterial pathogens.

Author Contributions: Conceptualization, D.P.-P. and C.J. Collection of samples and chemistry (extraction, isolation and chemical characterization), D.P.-P. and M.P.-P.; Taxonomic identification, P.G., S.G.-H., H.V.-H.; Biological assays, M.M.-G., C.L.-M., J.C.V.-U. and M.L.N.-O. Resources, G.B., J.R., A.B. and C.J. Writing original draft, D.P.-P. and C.J.; Writing review and editing, D.P.-P., G.B., J.R., A.B. and C.J. All authors have read and agreed to the published version of the manuscript.

Funding: This work was supported by Grants RTI2018-093634-B-C22 (AEI/FEDER, EU) from the State Agency for Research (AEI) of Spain, co-funded by the FEDER Programme from the European Union, by projects PI15/00860 and PI18/00501 to GB and PI14/00059 and PI17/01482 to AB (Instituto de Salud Carlos III) and BLUEBIOLAB (0474_BLUEBIOLAB_1_E), Programme INTERREG V A of Spain-Portugal (POCTEP). The study was also funded by projects IN607A 2016/22 (GAIN- Agencia Gallega de Innovación - Consellería de Economía, Emprego e Industria) and GRC2018/039 and Agrupación Estratégica CICA-INIBIC ED431E 2018/03 (Consellería de Educación, Universidades e Formación Profesional) from the Xunta de Galicia (autonomous government of the region). Support was also provided by Planes Nacionales de I+D+i 2013-2016 and ISCIII, Subdirección General de Redes y Centros de Investigación Cooperativa, Ministerio de Economía y Competitividad, Spanish Network for Research in Infectious Diseases (REIPI RD16/0016/006) co-financed by European Development Regional Fund "A way to achieve Europe" and the operative program Intelligent Growth 2014-2020. J.C.V.U. was financially supported by the pFIS Programme (FI18/00315), M.M.G. was financially supported by a Clara Roy grant (SEIMC) and C.L.M. by IN606A-2019/029. D.P.P. received a fellowship from the program National Council of Science and Technology (CONACYT) of Mexico and the Secretariat of Research, Innovation and Higher Education (SIIES) of Yucatan (Mexico).

Conflicts of Interest: The authors declare no conflict of interest.

\section{References}

1. Maxwell, D. Beyond Maritime Symbolism: Toxic marine objects from ritual contexts at Tikal. Anc. Mesoam. 2000, 11, 91-98. [CrossRef]

2. Voultsiadou, E. Therapeutic properties and uses of marine invertebrates in the ancient Greek world and early Byzantium. J. Ethnopharmacol. 2010, 130, 237-247. [CrossRef] 
3. O'Neill, J. Review on Antimicrobial Resistance. Tackling Drug-Resistant Infections Globally; World Health Organization (WHO): Geneva, Switzerland, 2016.

4. World Health Organization (WHO). WHO Priority Pathogens List for R\&D of New Antibiotics. 2017. Available online: https://www.who.int/medicines/publications/WHO-PPL-Short_Summary_25Feb-ET_NM_ WHO.pdf (accessed on 17 June 2020).

5. Maragakis, L.L.; Perl, T.M. Acinetobacter baumannii: Epidemiology, Antimicrobial Resistance, and Treatment Options. Clin. Infect. Dis. 2008, 46, 1254-1263. [CrossRef] [PubMed]

6. Meletis, G. Carbapenem resistance: Overview of the problem and future perspectives. Ther. Adv. Infect. Dis. 2015, 3, 15-21. [CrossRef]

7. Gales, A.C.; Jones, R.N.; Sader, H.S. Contemporary activity of colistin and polymyxin B against a worldwide collection of Gram-negative pathogens: Results from the SENTRY Antimicrobial Surveillance Program (2006-09). J. Antimicrob. Chemother. 2011, 66, 2070-2074. [CrossRef] [PubMed]

8. Isler, B.; Doi, Y.; Bonomo, R.A.; Paterson, D.L. New Treatment Options Against Carbapenem-Resistant Acinetobacter baumannii Infections. Antimicrob. Agents Chemother. 2019, 63, 1-18.

9. Kong, D.X.; Jiang, Y.Y.; Zhang, H.Y. Marine natural products as sources of novel scaffolds: Achievement and concern. Drug Discov. Today 2010, 15, 884-886. [CrossRef]

10. Hu, Y.; Chen, J.; Hu, G.; Yu, J.; Zhu, X.; Lin, Y.; Chen, S.; Yuan, J. Statistical Research on the Bioactivity of New Marine Natural Products Discovered during the 28 Years from 1985 to 2012. Mar. Drugs 2015, 13, 202-221. [CrossRef]

11. Jiménez, C. Marine Natural Products in Medicinal Chemistry. ACS Med. Chem. Lett. 2018, 9, 959-961. [CrossRef]

12. Cuevas, C.; Francesch, A. Development of Yondelis ${ }^{\circledR}$ (trabectedin, ET-743). A semisynthetic process solves the supply problem. Nat. Prod. Rep. 2009, 26, 322-337. [CrossRef]

13. Katz, J.; Janik, J.E.; Younes, A. Brentuximab Vedotin (SGN-35). Clin. Cancer Res. 2011, 17, 6428-6436. [CrossRef] [PubMed]

14. Altmann, K.H. Drugs from the Oceans: Marine Natural Products as Leads for Drug Discovery. Chimia 2017, 71, 646-652. [CrossRef] [PubMed]

15. Carroll, A.R.; Copp, B.R.; Davis, R.A.; Keyzers, R.A.; Prinsep, M.R. Marine Natural Products. Nat. Prod. Rep. 2019, 36, 122-173. [CrossRef] [PubMed]

16. Bye, R.; Linares, E.; Estrada, E. Biological diversity of medicinal plants in Mexico. In Phytochemistry of Medicinal Plants, Recent Advances in Phytochemistry; Arnason, J.T., Mata, R., Romeo, J.T., Eds.; Plenum Press: New York, NY, USA, 1995; Volume 29, p. 65.

17. Hernández-Bolio, G.I.; Ruiz-Vargas, J.A.; Peña-Rodríguez, L.M. Natural Products from the Yucatecan Flora: Structural Diversity and Biological Activity. J. Nat. Prod. 2019, 82, 647-656. [CrossRef]

18. Pech-Puch, D.; Pérez-Povedano, M.; Lenis-Rojas, O.A.; Rodríguez, J.; Jiménez, C. Marine Natural Products from the Yucatan Peninsula. Mar. Drugs 2020, 18, 59. [CrossRef]

19. Morales, J.L.; Cantillo-Ciau, Z.; Sánchez-Molina, I.; Mena-Rejón, G. Screening of Antibacterial and Antifungal Activities of Six Marine Macroalgae from Coast of Yucatan Peninsula. Pharm. Biol. 2006, 4, 632-635. [CrossRef]

20. Freile-Pelegrín, Y.; Morales, J.L. Antibacterial activity in marine algae from the coast of Yucatan, Mexico. Bot. Mar. 2004, 47, 140-146. [CrossRef]

21. Zubia, M.; Robledo, D.; Freile-Pelegrin, Y. Antioxidant activities in tropical marine macroalgae from the Yucatan Peninsula, Mexico. J. Appl. Phycol. 2007, 19, 49-458. [CrossRef]

22. Morales-Landa, J.L.; Zapata-Pérez, O.; Cedillo-Rivera, R.; Segura-Puertas, L.; Simá-Álvarez, R.; Sánchez-Rodríguez, J. Antimicrobial, Antiprotozoal, and Toxic Activities of Cnidarian Extracts from the Mexican Caribbean Sea. Pharm. Biol. 2007, 45, 37-43. [CrossRef]

23. Moo-Puc, R.; Robledo, D.; Freile-Pelegrin, Y. Evaluation of selected tropical seaweeds for in vitro anti-trichomonal activity. J. Ethnopharmacol. 2008, 120, 92-97. [CrossRef]

24. De Lara-Issasi, G.; Álvarez-Hernández, S.; Collado-Vides, L. Ichtyotoxic activity of extracts from Mexican marine macroalgae. J. Appl. Phycol. 2000, 12, 45-52. [CrossRef]

25. Moo-Puc, R.; Robledo, D.; Freile-Pelegrín, Y. In vitro cytotoxic and antiproliferative activities of marine macroalgae from Yucatan, Mexico. Cienc. Mar. 2009, 35, 35-358. [CrossRef] 
26. Bohlin, L.; Sjöstrand, U.; Djerassi, C.; Sullivan, B. Minor and Trace Sterols in Marine Invertebrates. Part 20. $3 \beta$-Hydroxy-methyl-A-nor-Patinosterol and 3 $\beta$-Hydroxymethyl-A-nor-dinosterol. Two New Sterols with Modified Nucleus and Side-Chain from the Sponge Teichaxinella morchella. J. Chem. Soc. Perkin Trans. 1981, 1023-1028. [CrossRef]

27. García-Arredondo, A.; Rojas-Molina, A.; Ibara-Alvarado, C.; Lazcano-Pérez, F.; Arreguín-Espinosa, R.; Sánchez-Rodríguez, J. Composition and biological activities of the aqueous extracts of three scleractinian corals from the Mexican Caribbean: Pseudodiploria stigosa, Porites astreoides and Siderastrea siderea. J. Venom. Anim. Toxins 2016, 22, 2-14. [CrossRef] [PubMed]

28. Pech-Puch, D.; Rodríguez, J.; Cautain, B.; Sandoval-Castro, C.A.; Jiménez, C. Cytotoxic Furanoditerpenes from the Sponge Spongia tubulifera Collected in the Mexican Caribbean. Mar. Drugs 2019, 17, 416. [CrossRef] [PubMed]

29. Mulani, M.S.; Kamble, E.E.; Kumkar, S.N.; Tawre, M.S.; Pardesi, K.R. Emerging Strategies to Combat ESKAPE Pathogens in the Era of Antimicrobial Resistance: A Review. Front. Microbiol. 2019, 10, 539. [CrossRef] [PubMed]

30. European Committee on Antimicrobial Susceptibility Testing (EUCAST). Clinical Breakpoints and Dosing of Antibiotics. 2019. Available online: http://www.eucast.org/clinical_breakpoints/ (accessed on 17 June 2020).

31. Álvarez-Fraga, L.; Vázquez-Ucha, J.C.; Martínez-Guitián, M.; Vallejo, J.A.; Bou, G.; Beceiro, A.; Poza, M. Pneumonia infection in mice reveals the involvement of the feoA gene in the pathogenesis of Acinetobacter baumannii. Virulence 2018, 9, 496-509. [CrossRef]

32. Melander, R.J.; Zurawski, D.V.; Melander, C. Narrow-spectrum antibacterial agents. Med. Chem. Comm. 2018, 9, 12-21. [CrossRef]

33. Maxson, T.; Mitchell, D.A. Targeted treatment for bacterial infections: Prospects for pathogen-specific antibiotics coupled with rapid diagnostics. Tetrahedron 2016, 72, 3609-3624. [CrossRef]

34. Stout, E.P.; Yu, L.C.; Molinski, T.F. Antifungal Diterpene Alkaloids from the Caribbean Sponge Agelas citrina: Unified Configurational Assignments of Agelasidines and Agelasines. Eur. J. Org. Chem. 2012, 27, 5131-5135. [CrossRef]

35. Cychon, C.; Lichte, E.; Köck, M. The marine sponge Agelas citrina as a source of the new pyrrole-imidazole alkaloids citrinamines A-D and N-methylagelongine. Beilstein J. Org. Chem. 2015, 11, 2029-2037. [CrossRef]

36. Quintana, J.; Brango-Vanegas, J.; Costa, G.M.; Castellanos, L.; Arévalo, C.; Duque, C. Marine organisms as source of extracts to disrupt bacterial communication: Bioguided isolation and identification of quorum sensing inhibitors from Ircinia felix. Rev. Bras. Farmacogn. 2015, 25, 199-207. [CrossRef]

37. Mora-Cristancho, J.A.; Arévalo-Ferro, C.; Ramos, F.A.; Tello, E.; Duque, C.; Lhullier, C.; Falkenberg, M.; Schenkel, E.P. Antifouling Activities against Colonizer Marine Bacteria of Extracts from Marine Invertebrates Collected in the Colombian Caribbean Sea and on the Brazilian Coast (Santa Catarina). Z. Naturforsch. C 2011, 66, 515-526. [CrossRef] [PubMed]

38. Kazlauskas, R.; Lidgard, R.O.; Murphy, P.T.; Wells, R.J.; Blount, J.F. Brominated Tyrosine-Derived Metabolites from the Sponge Ianthella basta. Aust. J. Chem. 1981, 34, 765-786. [CrossRef]

39. Pettit, G.R.; Butler, M.S.; Williams, M.D.; Filiatrault, M.J.; Pettit, R.K. Isolation and structure of hemibastadinols 1-3 from the Papua New Guinea marine sponge Ianthella basta. J. Nat. Prod. 1996, 59, 927-934. [CrossRef]

40. Le Norcy, T.; Niemann, H.; Proksch, P.; Tait, K.; Linossier, I.; Réhel, K.; Hellio, C.; Faÿ, F. Sponge-inspired dibromohemibastadin prevents and disrupts bacterial biofilms without toxicity. Mar. Drugs 2017, 15, 222. [CrossRef]

41. García-Vilas, J.A.; Martínez-Poveda, B.; Quesada, A.R.; Medina, M.Á. Aeroplysinin-1, a Sponge-Derived Multi-Targeted Bioactive Marine Drug. Mar. Drugs 2016, 14, 1. [CrossRef]

42. Litaudon, M.; Guyot, M. Ianthelline, Un nouveau derive de la dibromo-3,5-tyrosine, isole de l'eponge Iantella ardis (Bahanas). Tetrahedron Lett. 1986, 4455-4456. [CrossRef]

43. Xu, N.J.; Sun, X.; Yan, X.J. A new cyclostellettamine from sponge Amphimedon compressa. Chin. Chem. Lett. 2007, 18, 947-950. [CrossRef]

44. Kelly, S.R.; Garo, E.; Jensen, P.R.; Fenical, W.; Pawlik, J.R. Effects of Caribbean sponge secondary metabolites on bacterial surface colonization. Aquat. Microb. Ecol. 2005, 40, 191-203. [CrossRef]

45. Lhullier, C.; Moritz, M.I.G.; Tabalipa, E.O.; Sardá, F.N.; Schneider, N.F.Z.; Moraes, M.H.; Constantino, L.; Reginatto, F.H.; Steindel, M.; Pinheiro, U.S.; et al. Biological activities of marine invertebrates extracts from the northeast brazilian coast. Brazilian J. Biol. 2020, 80, in press. [CrossRef] 
46. Arevabini, C.; Crivelenti, Y.D.; de Abreu, M.H.; Bitencourt, T.A.; Santos, M.F.; Berlinck, R.G.; Hajdu, E.; Beleboni, R.O.; Fachin, A.L.; Marins, M. Antifungal activity of metabolites from the marine sponges Amphimedon sp. and Monanchora arbuscula against Aspergillus flavus strains isolated from peanuts (Arachis hypogaea). Nat. Prod. Commun. 2014, 9, 33-36. [CrossRef] [PubMed]

47. Hua, H.M.; Peng, J.; Dunbar, D.C.; Schinazi, R.F.; de Castro Andrews, A.G.; Cuevas, C.; Garcia-Fernandez, L.F.; Kelly, M.; Hamann, M.T. Batzelladine alkaloids from the caribbean sponge Monanchora unguifera and the significant activities against HIV-1 and AIDS opportunistic infectious pathogens. Tetrahedron 2007, 63, 11179-11188. [CrossRef]

48. Bernan, V.S.; Roll, D.M.; Ireland, C.M.; Greenstein, M.; Maiese, W.M.; Steinberg, D.A. A study on the mechanism of action of sceptrin, an antimicrobial agent isolated from the South Pacific sponge Agelas mauritiana. J. Antimicrob. Chemoth. 1993, 32, 539-550. [CrossRef]

49. Walker, R.P.; Faulkner, D.J.; Van Engen, D.; Clardy, J. Sceptrin, an antimicrobial agent from the sponge Agelas sceptrum. J. Am. Chem. Soc. 1981, 103, 6772-6773. [CrossRef]

50. Zhang, X.; Xu, H.-Y.; Huang, A.M.; Wang, L.; Wang, Q.; Cao, P.-Y.; Yang, P.M. Antibacterial Meroterpenoids from the South China Sea Sponge Dysidea sp. Chem. Pharm. Bull. 2016, 64, 1036-1042. [CrossRef]

51. Albrizio, S.; Ciminiello, P.; Fattorusso, E.; Magno, S.; Pawlik, J.R. Amphitoxin, a new high molecular weight antifeedant pyridinium salt from the Caribbean sponge Amphimedon compressa. J. Nat. Prod. 1995, 58, 647-652. [CrossRef]

52. Schmitz, F.J.; Hollenbeak, K.H.; Campbell, D.C. Marine natural products: Halitoxin, toxic complex of several marine sponges of the genus Haliclona. J. Org. Chem. 1978, 43, 3916-3922. [CrossRef]

53. Turk, T.; Sepčić, K.; Mancini, I.; Guella, G. 3-Akylpyridinium and 3-alkylpyridine compounds from marine sponges, their synthesis, biological activities and potential use. Stud. Nat. Prod. Chem. 2008, 35, 355-397.

54. Kelman, D.; Kashman, Y.; Hill, R.T.; Rosenberg, E.; Loya, Y. Chemical warfare in the sea: The search for antibiotics from Red Sea corals and sponges. Pure Appl. Chem. 2009, 81, 1113-1121. [CrossRef]

55. Kelman, D.; Kashman, Y.; Rosenberg, E.; Ilan, M.; Ifrach, I.; Loya, Y. Antimicrobial activity of the reef sponge Amphimedon viridis from the Red Sea: Evidence for selective toxicity. Aquat. Microb. Ecol. 2001, 24, 9-16. [CrossRef]

56. Berlinck, R.G.S.; Ogawa, C.A.; Almeida, A.M.P.; Sanchez, M.A.A.; Malpezzi, E.L.A.; Costa, L.V.; Hadju, E.; Freitas, J.C. Chemical and Pharmacological Characterization of Halitoxin from Amphimedon viridis (Porifera) from the southeastern Brazilian Coast. Comp. Biochem. Physiol. 1996, 115C, 155-163. [CrossRef]

57. Kelly, S.R.; Jensen, P.R.; Henkel, T.P.; Fenical, W.; Pawlik, J.R. Effects of Caribbean sponge extracts on bacterial attachment. Aquat. Microb. Ecol. 2003, 31, 175-182. [CrossRef]

58. Anta, C.; González, N.; Santafé, G.; Rodríguez, J.; Jiménez, C. New Xenia Diterpenoids from the Indonesian Soft Coral Xenia sp. J. Nat. Prod. 2002, 65, 766-768. [CrossRef]

59. Nakamura, H.; Wu, H.; Ohizumi, Y.; Hirata, Y. Agelasine-A, -B, -C and -D, novel bicyclic diterpenoids with a 9-methyladeninium unit possessing inhibitory effects on $\mathrm{Na}$, K-atpase from the okinawa sea sponge Agelas sp. Tetrahedron Lett. 1984, 25, 2989-2992. [CrossRef]

60. Wu, H.; Nakamura, H.; Kobayashi, J. Structures of agelasines, diterpenes having a 9-methyladeninium chromophore isolated from the Okinawan marine sponge Agelas nakamurai Hoshino. Bull. Chem. Soc. Jpn. 1986, 59, 2495-2504. [CrossRef]

61. Fu, X.; Schmitz, F.J.; Tanner, R.S.; Kelly-Borges, M. Agelasines H and I, 9-methyladenine-containing diterpenoids from an Agelas sponge. J. Nat. Prod. 1998, 61, 548-550. [CrossRef]

62. Iwagawa, T.; Kaneko, M.; Okamura, H.; Nakatani, M.; Van Soest, R.W.M. New alkaloids from the Papua New Guinean sponge Agelas nakamurai. J. Nat. Prod. 1998, 61, 1310-1312. [CrossRef]

63. Arai, M.; Yamano, Y.; Setiawan, A.; Kobayashi, M. Identification of the target protein of agelasine D, a marine sponge diterpene alkaloid, as an anti-dormant mycobacterial substance. Chem. Bio. Chem. 2014, 15, 117-123. [CrossRef]

64. Abdjul, D.B.; Yamazaki, H.; Kanno, S.I.; Takahashi, O.; Kirikoshi, R.; Ukai, K.; Namikoshi, M. Structures and Biological Evaluations of Agelasines Isolated from the Okinawan Marine Sponge Agelas nakamurai. J. Nat. Prod. 2015, 78, 1428-1433. [CrossRef]

65. Chu, M.J.; Tang, X.L.; Qin, G.F.; Sun, Y.T.; Li, L.; de Voogd, N.J.; Li, P.L.; Li, G.Q. Pyrrole Derivatives and Diterpene Alkaloids from the South China Sea Sponge Agelas nakamurai. Chem. Biodivers. 2017, 14, e1600446. [CrossRef] [PubMed] 
66. Hong, L.L.; Sun, J.B.; Yang, F.; Liu, M.; Tang, J.; Sun, F.; Jiao, W.H.; Wang, S.P.; Zhang, W.; Lin, H.W. New diterpene alkaloids from the marine sponge Agelas mauritiana. RSC Adv. 2017, 7, 23970-23976. [CrossRef]

67. Raub, M.; Cardellina, J.; Spande, T. The piclavines, antimicrobial indolizidines from the tunicate Clavelina picta. Tetrahedron Lett. 1992, 33, 2257-2260. [CrossRef]

68. Bianco, É.M.; Krug, J.L.; Zimath, P.L.; Kroger, A.; Paganelli, C.J.; Boeder, A.M.; Dos Santos, L.; Tenfen, A.; Ribeiro, S.M.; Kuroshima, K.N.; et al. Antimicrobial (including antimollicutes), antioxidant and anticholinesterase activities of Brazilian and Spanish marine organisms evaluation of extracts and pure compounds. Rev. Bras. Farmacogn. 2015, 25, 668-676. [CrossRef]

69. Arumugam, V.; Venkatesan, M.; Ramachandran, K.; Ramachandran, S.; Palanisamy, S.K.; Sundaresan, U. Purification, Characterization and Antibacterial Properties of Peptide from Marine Ascidian Didemnum sp. Int. J. Pept. Res. Ther. 2020, 26, 201-208. [CrossRef]

70. Jaffarali, H.A.; Tamilselvi, M.; Sivakumar, V. Antibacterial activity of the marine ascidians Phallusia nigra and Herdmania pallida from the Tuticorin coast, India. J. Biol. Res.Thessal. 2008, 10, 171-179.

71. Zidar, N.; Montalvão, S.; Hodnik, Ž.; Nawrot, D.; Žula, A.; Ilaš, J.; Kikelj, D.; Tammela, P.; Mašič, L.P. Antimicrobial Activity of the Marine Alkaloids, Clathrodin and Oroidin, and Their Synthetic Analogues. Mar. Drugs 2014, 12, 940-963. [CrossRef]

72. Nguyen, L.V.; Jamison, T.F. Total Synthesis of ( \pm )-Sceptrin. Org. Lett. 2020. Article ASAP. [CrossRef]

73. Marques, D.N.; De Almeida, A.S.; de Oliveira Sousa, A.R.; Pereira, R.; Andrade, A.L.; Chaves, R.P.; Carneiro, R.F.; De Vasconcelos, M.A.; Do Nascimiento-Neto, L.G.; Pinheiro, U.; et al. Antibacterial activity of a new lectin isolated from the marine sponge Chondrilla caribensis. Int. J. Biol. Macromol. 2018, 109, 1292-1301. [CrossRef]

74. Sepčić, K.; Kauferstein, S.; Mebs, D.; Turk, T. Biological Activities of Aqueous and Organic Extracts from Tropical Marine Sponges. Mar. Drugs 2010, 8, 1550-1566. [CrossRef]

75. Arai, M.; Yamano, Y.; Kamiya, K.; Setiawan, A.; Kobayashi, M. Anti-dormant mycobacterial activity and target molecule of melophlins, tetramic acid derivatives isolated from a marine sponge of Melophlus sp. J. Nat. Med. 2016, 70, 467-475. [CrossRef] [PubMed]

76. Laport, M.S.; Marinho, P.R.; da Silva Santos, O.C.; de Almeida, P.; Romanos, M.T.V.; Muricy, G.; Brito, M.A.V.P.; Giambiagi-deMarval, M. Antimicrobial activity of marine sponges against coagulase-negative staphylococci isolated from bovine mastitis. Vet. Microbiol. 2012, 155, 362-368. [CrossRef] [PubMed]

77. De Oliveira, M.F.; De Oliveira, J.H.; Galetti, F.C.; De Souza, A.O.; Silva, C.L.; Hajdu, E.; Peixinho, S.; Berlinck, R.G. Antimycobacterial Brominated Metabolites from Two Species of Marine Sponges. Planta Med. 2006, 72, 437-441. [CrossRef] [PubMed]

(C) 2020 by the authors. Licensee MDPI, Basel, Switzerland. This article is an open access article distributed under the terms and conditions of the Creative Commons Attribution (CC BY) license (http://creativecommons.org/licenses/by/4.0/). 